ARCHEION, T. CXX

WARSZAWA 2019

ISSN 0066-6041

e-ISSN 2658-1264

DOI 10.4467/26581264ARC.19.010.11819

JANUSZ ŁOSOWSKI

ORCID $0000-0003-1223-4288$

jalosowski@op.pl

(Uniwersytet Marii Curie-Skłodowskiej w Lublinie)

\title{
„LEGIONY”. ROZDZIAE WSPOMNIEŃ KAZIMIERZA KONARSKIEGO USUNIĘTY PRZEZ PEERELOWSKĄ CENZURĘ
}

Słowa kluczowe: Kazimierz Konarski, Polska Akademia Nauk Archiwum w Warszawie, Legiony Polskie, wojna polsko-bolszewicka, Kostiuchnówka

\section{Streszczenie}

Kazimierz Konarski (1886-1972) to najwybitniejszy polski archiwista okresu międzywojennego i pierwszych lat powojennych, legitymujący się bogatym dorobkiem archiwalnym oraz naukowym. Pozostawił po sobie wspomnienia opublikowane w roku 1965, stanowiące cenne źródło dla badaczy dziejów polskiej inteligencji. Jednak pominięto w nich jeden rozdział poświęcony służbie przyszłego archiwisty w 5. pułku piechoty Legionów Polskich w 1917 r. Na jego publikację nie zgodziła się komunistyczna cenzura, o czym świadczy adnotacja dokonana przez Konarskiego na maszynopisie rozdziału, który ofiarował swojemu koledze Piotrowi Bańkowskiemu. Usunięty fragment wspomnień został odnaleziony przez autora tego tekstu w spuściźnie archiwisty przechowywanej w warszawskim archiwum Polskiej Akademii Nauk. Wspomnienia dotyczące legionowego epizodu biografii późniejszego archiwisty stanowią interesujące źródło historyczne. Zawierają wiele wartościowych szczegółów służby koszarowej Konarskiego w pułku. Ta jednostka legionowa została skierowana dla reorganizacji i uzupełnienia do Ostrowi Mazowieckiej, niedaleko od Warszawy, po stratach poniesionych w lipcu 1916 r. w słynnej bitwie pod Kostiuchnówką. Na początku swojej służby Konarski miał problem z akceptacją przez swoich kolegów, był bowiem od nich starszy o kilkanaście lat, górował nad nimi wykształceniem oraz doświadczeniem życiowym. Jednak nie wywyższał się i starał się jak najlepiej pełnić służbę szeregowego, co zjednało mu szacunek legionistów. Autor usuniętego rozdziału opisał w nim w sposób barwny sylwetki dowódców, późniejszych wyższych oficerów i polityków, m.in. Felicjana Sławoja-Składkowskiego, Michała Karaszewicza-Tokarzewskiego, Stefana Grota-Roweckiego, Tytusa Filipowicza i innych. W tekście znalazło się też sporo wartościowych informacji o życiu codziennym żołnierzy tego pułku. 
JANUSZ ŁOSOWSKI

ORCID 0000-0003-1223-4288

jalosowski@op.pl

(Maria Curie-Skłodowska University in Lublin)

\section{“LEGIONY”. A CHAPTER OF KAZIMIERZ KONARSKI'S MEMOIRS, EXCISED BY CENSORSHIP OF POLISH PEOPLE'S REPUBLIC}

Keywords: Kazimierz Konarski, Polish Academy of Sciences Archive in Warsaw, Polish Legions, Polish-Bolshevik War, Kostiukhnivka

\section{Summary}

Kazimierz Konarski (1886-1972) was a preeminent Polish archivist in the interwar period and in afterwar years, with rich archival and academic legacy. In 1965, his memoirs were published, providing a valuable source of knowledge to researchers of Polish intelligentsia. However, from these memoirs one chapter was removed, depicting the future archivist's service in the $5^{\text {th }}$ Infantry Regiment of the Polish Legions in 1917. Communist censors prohibited its publication, as stated by Konarski's handwritten annotation on the typescript of the chapter gifted to his colleague, Piotr Bańkowski. The excised part of the memoirs was found by the author of this article in Konarski's legacy, preserved in Warsaw archive of the Polish Academy of Sciences. The part of the memoirs which pertains to the archivist's-to-be time in the Legions are an interesting historical source. It contains a number of valuable details regarding Konarski's service in the regiment named above. After the losses suffered in July 1916 in the famous battle of Kostiukhnivka, the unit was sent to Ostrów Mazowiecka near Warsaw to regroup and replenish the ranks. At the beginning of his service, Konarski had problems with getting accepted by his colleagues, as he was several years older than them, was better educated and had more life experience. However, he was not haughty and tried his best to serve as a private, which earned him respect of the legionnaires. In the removed chapter, the author vividly described the commanding officers, who subsequently became military leaders and politicians, including Felicjan Sławoj-Składkowski, Michał Karaszewicz-Tokarzewski, Stefan Grot-Rowecki, Tytus Filipowicz and others. There is also a lot of valuable information about daily life of the soldiers in the regiment. 
Profesor Kazimierz Konarski (1886-1972), najwybitniejszy archiwista polski okresu międzywojennego i pierwszych lat powojennych, a także wytrawny historyk, pozostawił po sobie wspomnienia, wartościowe z informacyjnego punktu widzenia i interesująco napisane. Zostały one wydane drukiem przez zasłużoną oficynę wydawniczą Ossolineum ${ }^{1}$ i przez wiele lat były uznawane jako całość, która została opublikowana zgodnie $\mathrm{z}$ wolą autora. W czasie przeglądu spuścizny archiwisty, przechowywanej w warszawskim archiwum Polskiej Akademii Nauk, nieoczekiwanie odnaleziono nieopublikowany w wymienionej książce maszynopis 13. rozdziału poświęconego ponad półrocznej służbie Konarskiego w 5. pułku piechoty Legionów Polskich, stacjonującym w Komorowie-Ostrowi i Zambrowie.

Tego rozdziału wspomnień zasłużonego archiwisty nie znała autorka poświęconego mu słownikowego biogramu, która również nie wiedziała o legionowym epizodzie w życiu Konarskiego ${ }^{2}$. Spowodowało to, że również środowisko archiwistów w przeważającej mierze nie było świadome legionowego epizodu w jego życiu, poza kręgiem jego warszawskich kolegów ${ }^{3}$. Dlatego o tym cennym znalezisku poinformowano czytelników w artykule poświęconym wspomnieniom Konarskiego z okresu II wojny światowej ${ }^{4}$. Znacznie więcej informacji o usuniętym rozdziale zamieszczono w odrębnym tekście, starając się ukazać jego przydatność jako źródła historycznego zarówno do badań biografii archiwisty, jak i dziejów Legionów ${ }^{5}$.

Szerzej nieznany rozdział wspomnień Konarskiego opatrzony tytułem „Legiony" nie został opublikowany ze względu na negatywną decyzję cenzury, zapewne wrocławskiej. Zbadanie okoliczności tej szkodliwej decyzji cenzorskiej pozwoliłoby na ustalenie przyczyny usunięcia rozdziału i dokonania innych ingerencji, które spowodowały usunięcie wybranych fragmentów ostatniego rozdziału wspomnień. Autor wyrażał w nich krytyczne opinie, zresztą ogólnikowo i łagodnie, o rodzącym się nowym porządku politycznym w Polsce. Niestety, nie ma już materiałów źródłowych, na których podstawie można byłoby ustalić powody ingerencji cenzorskich. Dokumentacja tej sprawy nie zachowała się w archiwum wydawnictwa Ossolineum, które wydało książkę .

${ }^{1}$ K. Konarski, Dalekie a bliskie. Wspomnienia szczęśliwego człowieka, Wrocław 1965.

2 W. Maciejewska, Konarski Kazimierz Bogdan, [w:] Słownik biograficzny archiwistów polskich, t. 1, 1918-1984, red. M. Bielińska i I. Janosz-Biskupowa, Warszawa-Lódź 1988, s. 104-106.

${ }^{3}$ P. Bańkowski, Kazimierz Konarski (1886-1972), „Archeion” 1973, t. 59, s. 348.

${ }^{4}$ J. Łosowski, Wspomnienia Kazimierza Konarskiego z okresu wojny jako obraz przeżyć jednostki w okresie zmagań z dwoma systemami totalitarnymi, [w:] Wkład archiwistów warszawskich $w$ rozwój archiwistyki polskiej. Zbiór studiów poświęconych warszawskiemu środowisku archiwalnemu, red. A. Kulecka, Warszawa 2012, s. 330.

${ }^{5}$ Idem, Wspomnienia legionowe Kazimierza Konarskiego, [w:] Zarzadzanie dokumentacja, archiwistyka i... koty. Księga jubileuszowa Profesor Haliny Robótki, red. R. Degen, M. Jabłońska, W.K. Roman, Toruń 2016, s. 217-226.

${ }^{6}$ Pismo Andrzeja Głuchowskiego, Prezesa Zarządu Wydawnictwa Zakładu Narodowego im. Ossolińskich, do Janusza Łosowskiego z 28 września 2011 r., znak: PZ/1352/2011. 
Nie wiadomo, co stało się z aktami wrocławskiej cenzury, czyli działającego tam Wojewódzkiego Urzędu Kontroli Prasy, Publikacji i Widowisk, który opiniował wszelkie publikacje wydawane na terenie województwa. Z informacji udzielonej przez Archiwum Państwowe we Wrocławiu wynika, że nie przekazano do niego żadnych akt tej instytucji ${ }^{7}$, co może dziwić, ponieważ dokumentacja urzędów cenzury z innych województw została przejęta przez archiwa (np. w Poznaniu czy Lublinie). Także próba poszukiwania informacji dotyczących tej spraw w warszawskim Archiwum Akt Nowych nie przyniosła żadnych rezultatów ${ }^{8}$.

Bezpośrednim i jedynym dowodem na eliminację pechowego rozdziału przez ten organ politycznej kontroli kultury i nauki, jakim była cenzura, stała się adnotacja dokonana przez Konarskiego na zachowanym maszynopisie. Sporządził ją w dniu 14 listopada 1967 r., w którym podarował tekst swojemu przyjacielowi Piotrowi Bańkowskiemu9. Autor uczynił to pięć lat przed śmiercią. Miał już wtedy 81 lat, od siedmiu lat był emerytem i zapewne zdawał sobie sprawę $\mathrm{z}$ nadchodzącego kresu życia. Przypuszczalnie zależało mu, aby tekst rozdziału, z którym nie mogli zapoznać się czytelnicy, trafił w godne ręce i nie zaginął, a w przyszłości został wykorzystany przez badaczy.

Piotr Bańkowski (1885-1976), obecnie już zapomniany archiwista, był także historykiem literatury i bibliotekarzem. W roku 1905 uczestniczył w strajku w gimnazjum filologicznym w Łomży, w następstwie czego został usunięty $\mathrm{z}$ tej szkoły ${ }^{10}$. Potem studiował na Uniwersytecie Jagiellońskim historię literatury, uzyskując w 1912 r. doktorat. Jako stypendysta Kasy im. J. Mianowskiego przebywał w Paryżu, stamtąd w 1915 r. wyjechał do Petersburga, skąd powrócił do kraju w 1918 r. ${ }^{11}$ W latach 1918-1924 pracował w Archiwum Państwowym w Lublinie, okresowo zastępując dyrektora prof. Stanisława Ptaszyckiego, gdy został on oddelegowany do Wilna. W latach 1927-1934 był członkiem Delegacji Polskiej przy Mieszanej Komisji Polsko-Radzieckiej do spraw rewindykacji dóbr kultury. Następnie do 1940 r. pracował jako kustosz działu rękopisów Biblioteki Narodowej w Warszawie, a po jej zamknięciu przez niemieckie władze okupacyjne był zatrudniony w Archiwum Skarbowym ${ }^{12}$. Od 1945 r. pracował w Wydziale

\footnotetext{
${ }^{7}$ Pismo do Janusza Łosowskiego z dnia 14 lutego 2018 r. (znak: OIII.6342.113.2018), podpisane przez zastępcę dyrektora Remigiusza Kazimierczaka.

${ }^{8} \mathrm{~W}$ archiwum tym w zespole Głównego Urzędu Kontroli Prasy, Publikacji i Widowisk znajduje się kilkadziesiąt teczek dotyczących wrocławskiego oddziału, jednak nie mogły być one udostępnione ze względu na przeprowadzane prace ewidencyjne i konserwatorskie (Pismo do Janusza Łosowskiego z dnia 27 marca 2018 r., znak: III.6342.429.2018, podpisane przez kierownika Oddziału III Ewidencji i Przechowywania Zasobu Eugenię Szymczuk).

${ }^{9}$ Zob. informację zamieszczoną pod prezentowanym dokumentem, s. 232.

${ }_{10}$ M. Bielińska, M. Wąsowicz, Bańkowski Piotr, [w:] Stownik biograficzny..., t. 1, s. 32.

${ }^{11}$ Ibidem.

12 Ibidem, s. 33.
} 
Archiwów Państwowych, gdzie kierował pracami wydawniczymi archiwów państwowych oraz współredagował „Archeion” ${ }^{13}$. Po krótkim okresie zatrudnienia w warszawskim Archiwum Głównym Akt Dawnych przeszedł w marcu 1951 r. do Naczelnej Dyrekcji Archiwów Państwowych, gdzie kontynuował kierowanie działem naukowo-wydawniczym oraz redagowanie „Archeionu”14. Tym czasopismem zajmował się także po przejściu na emeryturę w roku 1962 i był z nim związany aż do śmierci w $1976 \mathrm{r}$.

W uznaniu dorobku naukowego Bańkowski w 1954 r. został mianowany docentem, a w 1962 r. profesorem nadzwyczajnym ${ }^{15}$. Jego bibliografia liczy około 180 prac, wśród których najważniejsze miejsce zajmuje monografia archiwoznawcza, poświęcona archiwum króla Stanisława Augusta, opublikowana w roku 1958. Osiągnięcia w pracy redakcyjnej tego archiwisty są zaiste imponujące, ponieważ kierował redakcją aż 44 tomów „Archeionu” z lat 1951-1976. Ze względu na rozległy i zróżnicowany dorobek naukowy, doświadczenia w pracy archiwalnej i bibliotecznej, pracę w Wydziale Archiwów Państwowych oraz w NDAP, a także sukcesy w pracy wydawniczej można go śmiało zaliczyć do elity polskich archiwistów. Ten wzgląd oraz więzi przyjaźni zdecydowały zapewne o powierzeniu mu przez Konarskiego nie tylko cennego maszynopisu, ale i innych materiałów aktowych ${ }^{16}$. Znali się od pobytu w Paryżu przed I wojną światową i należeli do jednego pokolenia, dobrze pamiętającego schyłkowy okres niewoli, które po zakończeniu I wojny światowej wznosiło podwaliny odrodzonego państwa.

W 1976 r. materiały po Kazimierzu Konarskim zostały przekazane do warszawskiego Archiwum PAN razem ze spuścizną Piotra Bańkowskiego na podstawie jego zapisu testamentalnego ${ }^{17}$. Wydzielono je więc $\mathrm{z}$ akt Bańkowskiego, a w roku 2007 uporządkowano oraz zinwentaryzowano za sprawą Anity Chodkowskiej, która opisała je też w oddzielnym artykule ${ }^{18}$. Obecnie liczą one 15 j.a. o objętości 0,24 m.b., a maszynopis legionowego rozdziału znajduje się w teczce o sygnaturze 11; jest to 26 ponumerowanych stron znormalizowanego tekstu, po 28-29 wierszy na stronie oraz 60-65 znaków w wierszu. Dokonano w nim drobnych korekt stylistycznych, usuwając lub zamieniając niektóre wyrazy oraz poprawiając drobne błędy fleksyjne i literowe.

Ze względów formalnych w tekście opisywanego rozdziału można wyróżnić dwie części. Zasadniczą część autor wspomnień spisał w latach 60. XX w. prawdopodobnie z pamięci (s. 1-20), chociaż posiłkował się też bliżej nieokreślonym

${ }^{13}$ Ibidem.

${ }^{14}$ Ibidem.

${ }^{15}$ Ibidem, s. 32.

${ }^{16}$ A. Chodkowska, Materiały Kazimierza Konarskiego (1886-1972), „Biuletyn Archiwum Polskiej Akademii Nauk" 2008, nr 49, s. 105.

17 Ibidem.

${ }^{18}$ Ibidem. 
brulionem. Druga, końcowa część wspomnień, odnosząca się do kryzysu przysięgowego roku 1917, została sporządzona nie tylko z pamięci, ale z wykorzystaniem dzienniczka, pisanego $\mathrm{w}$ trakcie dziejących się wydarzeń, nazwanego przez autora raptularzem ${ }^{19}$. Jako profesjonalny historyk, miał on świadomość znaczenia momentu legionowej epopei, którego stał się świadkiem. Dlatego codziennie prowadził zwięzłe notatki, zawierające opis zaobserwowanych faktów. Po 40 latach wprowadził je do rozdziału, dokonując w nich jedynie, jak sam napisał, zmian redakcyjnych i stylistycznych ${ }^{20}$. Tę część tekstu wyróżnia odmienna struktura, ponieważ w odróżnieniu od opisów, refleksji i komentarzy, charakteryzujących poprzednie rozdziały, zawiera zapiski z poszczególnych dni, począwszy od 6 lipca i kończące się na 19 lipca. W końcowej części rozdziału autor dokonał podsumowania swojej służby legionowej oraz opisał okoliczności podjęcia pracy jako urzędnika w Departamencie Wyznań Religijnych i Oświecenia Publicznego Tymczasowej Rady Stanu ${ }^{21}$.

Wartość źródłową tego rozdziału oceniono we wspomnianym już artykule, dlatego w tym miejscu zostaną wskazane najważniejsze ustalenia. Wbrew oczekiwaniom nie wnosi on wiele do dziejów 5. pułku, ponieważ w okresie służby Konarskiego, po chwalebnym szlaku bojowym, a szczególnie w bitwie pod Kostiuchnówką, został wycofany $\mathrm{z}$ frontu $\mathrm{w}$ celu reorganizacji oraz uzupełnienia i skierowany do Komorowa-Ostrowi, a potem do Zambrowa i na skutek kryzysu przysięgowego przestał istnieć. Autor wspomnień jako szeregowy miał za niską rangę wojskową, aby poznać problemy dowodzenia jednostką w czasie jej stacjonowania $\mathrm{z}$ dala od frontu i fachowo ocenić jej funkcjonowanie w tym okresie. $\mathrm{Z}$ tych względów nawet nie próbował tego czynić.

Natomiast interesująco przedstawił swoją sytuację inteligenta, który z własnej woli znalazł się wśród prostych żołnierzy i musiał pokonać liczne problemy adaptacyjne, aby stać się jednym z nich. Zupełnie do nich nie pasował, górując nad nimi wiekiem (był starszy o od nich przeciętnie o 10 lat), wykształceniem oraz doświadczeniem zawodowym. Mimo tego dzięki determinacji i skromności został zaakceptowany przez legionowych wiarusów. W jego wypadku służba wojskowa okazała się nie tylko przygodą, ale okresem wysiłku fizycznego i codziennych uciążliwości, które były bardziej dotkliwe dla trzydziestoletniego autora niż młodzieńca, który tylko co osiągnął pełnoletność.

Konarski świadomie podjął ten wysiłek, kierując się potrzebą służenia ojczyźnie, chociaż o motywacji swojej decyzji, zadziwiającej zwierzchników i zapewne krewnych, nie pisał wiele. A kwestię motywów wstąpienia do Legionów usiłował przysłonić, podając pozornie racjonalne uzasadnienie, czyli potrzebę wyzwolenia od „duszącego i przytłaczającego jarzma” pracy dydaktycznej

\footnotetext{
${ }^{19}$ Dokument w niniejszym artykule, s. 225-230.

${ }^{20}$ Ibidem, s. 225.

${ }^{21}$ Ibidem, s. 231.
} 
na Uniwersytecie. Ten powód podany przez byłego wykładowcę uniwersyteckiego trudno uznać za decydujący o podjęciu służby wojskowej, która przecież mogła zakończyć się dla niego śmiercią, kalectwem czy upokarzającą niewolą.

Drugą istotną zaletę rozdziału stanowią interesujące charakterystyki zwykłych żołnierzy, z którymi przyszły archiwista odbywał służbę w 5. pułku. Nie ma ich wiele, ale te, które zamieścił, są cenne i pozwalają lepiej zrozumieć społeczne zróżnicowanie środowiska legionowego oraz zachowania zwykłych żołnierzy w czasie ich koszarowej służby. Z niektórymi legionistami połączyły go więzy przyjaźni, doskonale ich poznał. $Z$ tego powodu opis ich zachowania wydaje się bardzo wiarygodny, a przez to szczególnie wartościowy i użyteczny dla badaczy.

$\mathrm{Na}$ uwagę badaczy zasługują też zawarte $\mathrm{w}$ tekście rozdziału uwagi o dowódcach, kompanii, batalionów i pułku, których Konarski miał okazję poznać w okresie legionowej służby. A były to osoby, które w okresie II Rzeczypospolitej weszły do elity wojskowej czy politycznej. Autor wspomnień nie oceniał ściśle wojskowych umiejętności swoich dowódców, ponieważ nie mógł ich poznać, nie walcząc pod ich dowództwem na froncie. Jednak niektóre szczegóły dotyczące ich zachowania w czasie służby garnizonowej na pewno zainteresują historyków i będą brane pod uwagę przy ocenie ich osobowości czy charakterów, zwłaszcza że zostały dokonane z pozycji zwykłego żołnierza, a nie oficera.

Pewną wartość informacyjną mają też zapiski autora dotyczące kryzysu przysięgowego. Bardzo dobrze odzwierciedlają one nastroje panujące w pułku. Rozwój wydarzeń, a szczególnie ich dynamika zaskoczyła go i zdezorientowała, podobnie jak i innych legionistów. Z treści notatek wyraźnie wynika, że Konarski nie bardzo rozumiał, co się działo wokół niego. W podobnej sytuacji byli też inni legioniści, stąd ich nastroje szybko się zmieniały, od stanu przygnębienia do euforii, w zależności od pogłosek, które do nich docierały. Autor był bezpośrednim świadkiem początkowej fazy kryzysu w swoim pułku, a potem wyjeżdżał, dlatego w swoim raptularzu notował przebieg wydarzeń na podstawie zasłyszanych informacji.

W dniu 13 lipca 1917 r. po odmowie złożenia przysięgi przez legionistów 5. pułku, Konarski został wysłany z Zambrowa do Ostrowi, aby przywieźć bliżej nieokreślone rzeczy należące do jego kompanii. Powrócił do swoich koszar 14 lipca, ale jeszcze po południu tego samego dnia wyjechał do Warszawy, prawdopodobnie w celach służbowych i tam pozostał do 17 lipca. O wydarzeniach, które zaszły w tym czasie w koszarach zambrowskich, dowiedział się z relacji innych osób, o czym wyraźnie napisał w tekście rozdziału ${ }^{22}$. W tym czasie jego kolegów, którzy nie złożyli przysięgi, Niemcy wywieźli do obozu w Szczypiornie. Po powrocie do koszar 18 lipca zastał w nich jedynie nielicznych żołnierzy, z którymi później został przewieziony do fortu w podprzemyskich Siedliskach.

${ }^{22}$ Ibidem, s. 229. 
Widząc koniec Legionów i obawiając się wcielenia do wojska austriackiego, uciekł stamtąd i przedostał się do krewnych mieszkających w Sandomierskiem. Po dwóch miesiącach w dniu 2 października 1917 r. objął stanowisko sekretarza generalnego Departamentu Wyznań Religijnych i Oświecenia Publicznego Tymczasowej Radzie Stanu w Warszawie.

Tekst rozdziału został przygotowany do wydania na podstawie projektu instrukcji wydawniczej dla źródeł historycznych XIX i początku XX w. opracowanego przez Ireneusza Ihnatowicza ${ }^{23}$. Zgodnie z nim dokonano modernizacji pisowni oraz poprawiono oczywiste błędy literowe maszynopisu. Zachowano też oryginalny podział na akapity. W celu ułatwienia zrozumienia treści publikowanego rozdziału w przypisach rzeczowych podano rozszerzone informacje o oficerach wzmiankowanych w tekście oraz kolejach ich życia, uwalniając tym samym czytelników od konieczności poszukiwania tych danych w publikacjach czy też w Internecie. Zamieszczono też podstawowe dane o miejscowościach wymienionych w tekście, ułatwiających określenie ich położenia. Podano również literaturę, z której czerpano informacje. Ze względu na niewielką objętość edytowanego tekstu nie sporządzono do niego indeksów. Objaśniono też użyte przez autora wyrazy obce, w większości już nieużywane we współczesnej polszczyźnie.

\section{[Warszawa, przed 1965 r.], Kazimierz Konarski, rozdział 13. Legiony}

Nie pamiętam, czy to był mój przysłowiowy czwartek, ale pamiętam, że w cudowny, mroźny, słoneczny dzień wylądowałem z wagonu na stacji Ostrów Mazowiecka $^{24}$. Uniform dano mi już w Warszawie, jechałem tedy już jako żołnierz. Duszę miał ów żołnierz zgoła nie po żołniersku ulokowaną wysoko na którymś z ramion. Serce w rozterce. Żebyż choć jedna znajoma twarz. Olbrzymia śnieżna, oślepiająca przestrzeń potęguje jeszcze uczucie mej samotności. Nie rozpraszają jej bynajmniej sylwetki kilku żołnierzy, którzy wysiedli razem ze mną. Gotów jestem podejrzewać, że nieostruganego drągala rekruta pokazują sobie oczyma.

Trzeba jednak wyjść z tej prostracji ${ }^{25}$ i działać. Ze stacji do koszar jest kilka kilometrów ${ }^{26}$. Trafia się jakaś furka, przysiadamy się na nią w kilku i jedziemy. Nadrabiam miną i zaczynam śpiewać piosenkę. Pamiętam nawet jaką:

${ }^{23}$ I. Ihnatowicz, Projekt instrukcji wydawniczej dla źródel historycznych XIX i początku XX wie$k u$, „Studia Źródłoznawcze” 1962, t. 7, s. 99-124.

${ }^{24}$ Ostrów, miasto powiatowe w gub. łomżyńskiej. Słownik geograficzny Królestwa Polskiego (dalej: SGKP), t. 7, Warszawa 1888, s. 696-697. Od 1926 r. nosiło ono nazwę Ostrów Mazowiecka. J. Kwiatek, T. Litewski, Leksykon miast polskich, Warszawa 1998, s. 599.

${ }^{25}$ Prostracja, skrajne wyczerpanie nerwowo-psychiczne. Stownik języka polskiego, red. W. Doroszewski, t. 7, Warszawa 1965, s. 62.

${ }^{26}$ Koszary znajdowały się w miejscowości Komorowo, odległej od stacji w Ostrowi Mazowieckiej o kilka kilometrów. W 1. 1891-1893 władze carskie zbudowały koszary, które zajmowały 23. 
Cztery koniki rysie.

A poplątały mi się,

A jakże ja dojadę.

A do mojej Marysi, Hej.

Dzwoniła w moim śpiewie jakaś fałszywa, nienaturalna nuta. Poczułem to od pierwszego tonu, ale już przerwać w pół słowa nie mogłem. Wyczułem to i w sąsiadach, którzy dziwnie jakoś spode łba przyglądają mi się, a jeden coś bąka o tym, że jedziemy z orkiestrą. Ten witz ${ }^{27}$, choć niby puszczony w przestrzeń, dekoncertuje mnie doszczętnie i odbiera chęć do wszelkich popisów wokalnych. W gorzko głupim milczeniu jedziemy dalej. Dojechaliśmy. Budynki koszarowe stoją długim szeregiem wzdłuż szosy ponure, nudne, groźne.

Wysiadamy. Zbieram informacje, zbieram odwagę w obie ręce i żegluję w kierunku jakiegoś wskazanego mi budynku. Czuję się niewypowiedzianie głupio w nieswojej skórze, nie wiem, czy jak i komu salutować, co robić z rękami, $\mathrm{z}$ nogami, które w takich sytuacjach robią się przerażająco długie, niezdarne, ciężkie. Do dziś pamiętam, jak w jednej z tych kancelarii zamiast zasalutować raz, a potem załatwiać, co miałem do załatwienia, salutowałem co chwila, na co mi w końcu zwrócono uwagę. Na ogół zresztą wyczuwałem od samego początku w postępowaniu władz ze mną jakieś momenty uprzejmego niezdecydowania, jakieś zakłopotane ,patyczkowanie się" z moją osobą, którego zaraz moja rekrucka dusza nie mogła zgoła pojąć. Domyśliłem się w końcu, że chodziło o mój dotychczasowy zawód. Profesor uniwersytetu w roli szeregowca nie był w piątym pułku wypadkiem codziennym i tym tłumaczyć należy tak obcy kancelarii wojskowej, a zwłaszcza leguńskiej zażenowany nastrój.

Była to dla mnie okoliczność i dodatnia i ujemna. Dodatnia, bo ów protekcjonalizm złagodził mi niewątpliwie moje początki służby wojskowej. Ujemna, bo budziła uwagę, że wszelki cień przywileju wytworzy atmosferę zazdrości w mym nowym koleżeńskim środowisku i gotów mi popsuć stosunki z nim, na to było dla mnie najważniejszym problemem dnia. Jechałem przecież do pułku $\mathrm{z}$ zamiarem absolutnego podporządkowania się panującym w nim regulaminom i zwyczajem i całkowitego zapomnienia o prerogatywach mego byłego cywilnego stanowiska, co uważałem - jak się potem okazało, słusznie - za jedyną taktykę wskazaną dla rekruta, który miał się zetknąć ze starym żołnierzem.

Najważniejszym objawem owego protekcjonalizmu było skierowanie mnie do batalionu rekruckiego, dotąd jako surowy zupełnie rekrut winienem był trafić, ale do pierwszego liniowego batalionu między starą wiarą. Posunięcie to

Niżowski Pułk Piechoty gen. feldmarszałka Sałtykowa oraz 24. Symbirski Pułk Piechoty. W czasie I wojny światowej stacjonowały tam oddziały niemieckie oraz w 1917 r. 5. pułk piechoty Legionów. W okresie międzywojennym koszary te zajmowała słynna Szkoła Podchorążych Piechoty, https:// dobroni.pl/n/spp-komorowo-kostrowii/4860 [dostęp: 12.06.2018].

${ }^{27}$ Witz, dowcip, żart. J. Karłowicz, A. Kryński, W. Niedźwiedzki, Stownik języka polskiego, t. 7, Warszawa 1919, s. 544. 
zdecydowało charakterze całej mej legionowej epopei. Zamiast rekruckiej gehenny wśród zbieraniny, która miała się urabiać dopiero i stopniowo za przykładem starej wiary dostrajać się do wysokiego kamertonu jej legionowej pieśni, miałem przed sobą zetknięcie się i współżycie bezpośrednio z tąż właśnie starą wiarą. Inna rzecz, że gdym się zetknął z tym niesłychanie zwartym, solidarnym, zamkniętym, zdawało się, na cztery spusty dla wszelkich intruzów światem, ogarnęło mnie zrazu przerażenie, bo wyobraziłem sobie, że ja nigdy nie zdołam przebić tej ściany, wejść wśród nich, przeniknąć, zżyć się z nimi, że moje rekructwo zostanie już jako niestarte na mej duszy plama, która nie pozwoli mi pochłonąć dystansu dzielącego mnie od starej wiary. Zapomniałem, że w duszy ludzkiej jest motor silniejszy niż wszystkie inne na świecie, zawsze zwycięski przyzwyczajenie.

Pierwsze chwile spędzone w pierwszej kompanii nie spełzną w mej pamięci aż do ostatniego mego tchu. Wprowadził mnie tam jakiś kapral, zaprezentował jako nowego kolegę, wykręcił się na pięcie i zostawił mnie oko w oko z kilkunastoma szlafkamratami ${ }^{28}$ lustrującymi oto nieufnie nowego przybysza.

Trafiłem na jakieś porządki, szorowanie podłogi. Kładę moje manatki na wyznaczoną mi pryczę i natychmiast zgłaszam się do wiadra i szczotki. Od razu widzę, że mój gest został dobrze przyjęty. Spojrzenia kierowane ku mnie przestają trącić wilkiem; potęguje to mój zapał do sprzątania. Nie słabnie on, gdy po korytarzu przyszła kolej na latrynę. Wstępnym tym bojem zdobyłem sobie drużynę i do wieczora już wiele lodu dokoła mojej osoby wytajało.

Okolicznością sprzyjającą moim pierwszym krokom na terenie koszar, bo odciągającą uwagę od nowego rekruta była sensacja, jaka zbiegła się prawie co do godziny z początkiem mej służby wojskowej. Ni mniej ni więcej, tylko aresztowanie naszego komendanta kompanii por. Wąsika ${ }^{29}$.

O co poszło, nie wiem. Więźnia po paru dniach wypuszczono i przywrócono mu jego funkcje tak, że zarzuty musiały okazać się niesłuszne, ale huku narobiła ta sprawa dużo, zagłuszając, jak mówię, doszczętnie inną sensację, jaka mogła była stać się na podwórku koszarowym pojawienie się uniwersyteckiego dziennikarza.

Minął dzień, drugi, trzeci i sytuacja moja zaczęła się szybko wyjaśniać. Arkana wiedzy koszarowej nie były tak znów bardzo skomplikowane i przy odrobinie już nawet nie gorliwości, ale po prostu dobrej woli dały się opanować bardzo łatwo i prędko, z każdym dalszym dniem nabierałem w tym wprawy i co było bardzo ważne dla ówczesnego stanu psychiki - pewności siebie.

\footnotetext{
${ }^{28}$ Szlafkamrat, współmieszkający w jednym pokoju. Ibidem, t. 6, Warszawa 1915, s. 630.

${ }^{29}$ Podporucznik Władysław Wąsik, oficer 5. pułku piechoty, potem kapitan i major, odznaczony Krzyżem Virtuti Militari V klasy. Jego zdjęcie z 1916 r. jako podporucznika, http://docplayer. pl/20870731-9-kpt-aleksander-luczynski-ps-narbut-komendant-1-batalionu-5-pulku-piechoty-legionow-polskich-pozycje-pod-kostiuchnowka-czerwiec-1916.html [dostęp: 12.06.2018].
} 
Wierny moim założeniom i zamiarom całkowitego zasymilowania się z masą żołnierską, uniknąłem jak najstaranniej wszelkiego kontaktu z szarżami oficerskimi. Przy niewielkim na ogół dystansie dzielącym legionowego oficera od szarej braci żołnierskiej nie było to bynajmniej trudne i miałem kolegów, którzy długie godziny spędzali w kasynie oficerskim. Czynił tak między innymi i kapral Tytus Filipowicz ${ }^{30}$ i o ile pamiętam dawał mi do zrozumienia, że jeślibym chciał, ułatwiłby mi przekroczenie tych progów. Ja wszakże obawiałem się je przekraczać, by nie narazić na szwank kiełkujących dopiero nieśmiało zalążków przyjaźni z moimi szarymi komilitonami i zachowałem się odpornie wobec tych pokus.

Tym się tłumaczy, że tak mało dziś mogę powiedzieć o oficerskim zespole 5 pułku.

Komendant pułku, Berbecki ${ }^{31}$, był dla mnie mitem. Znałem go raczej z widzenia $\mathrm{i}$ to bodaj z późniejszych zajęć, ze wspólnych posiedzeń czy po prostu $\mathrm{z}$ warszawskich fajfów ${ }^{32}$. W pułku wtedy prawie się go nie widziało; na razie leczył swoje rany spod Kostiuchnówki ${ }^{33}$, potem ugrzązł w polityce w stosunkach z Radą Stanu ${ }^{34}$. W pułku był lubiany bardzo, dopiero owa Rada Stanu niepopularna bardzo u legunów ${ }^{35}$, zachwiała nieco jego autorytetem i mirem, jakim się cieszył u żołnierzy. Wiedziano, że bój pójdzie z nimi zawsze w pierwszej linii i że o żołnierzy swoich dba jak ojciec o rodzone dzieci. Stąd dwuwiersz rosyjski, którym go charakteryzowano: „połkownik nasz rożdion był chwatem. Sługa cariu, otiec sołdatam"36. Inne rosyjskie charakteryzujące go słówko „zuboczist”, to jest człowiek bijący żołnierzy po zębach, było chyba złośliwą kalumnią nawiązującą może do porywczego charakteru naszego Berbecia.

${ }^{30}$ Tytus Filipowicz (1873-1953), działacz PPS i bliski współpracownik Józefa Piłsudskiego. W 1914 r. wstąpił do Legionów, a następnie do Naczelnego Komitetu Narodowego. W okresie międzywojennym poseł RP w Finlandii, Belgii, a potem ambasador w USA (1929-1932), od 1930 r. również poseł w Meksyku. Zmarł na emigracji. Stownik biograficzny historii Polski, pod red. J. Chodery i F. Kiryka, t. 1, Wrocław 2005, s. 401.

${ }^{31}$ Leon Berbecki (1874-1963), służył jako oficer w armii rosyjskiej i wziął udział w wojnie rosyjsko-japońskiej, dowodząc kompanią i batalionem, a potem przeszedł do rezerwy. Rozpoczął studia w Charkowskim Instytucie Technologicznym, które ukończył z wyróżnieniem. Był członkiem PPS i Związku Walki Czynnej na Ukrainie. W 1914 r. wstąpił do Legionów i dowodził kompanią, batalionem, a następnie 5. pułkiem piechoty. P. Stawecki, Stownik biograficzny generałów Wojska Polskiego 1918-1939, Warszawa 1994, s. 74-75.

${ }^{32}$ Fajf, przyjęcie popołudniowe urządzane na wzór angielski o godzinie piątej po południu. Słownik wyrazów obcych PWN, red. J. Tokarski, Warszawa 1980, s. 208.

${ }^{33}$ Chodzi o słynną bitwę pod Kostiuchnówką (4-6 lipca 1916 r.), w której oddziały legionowe (w sile trzech brygad) liczące 16 tys. legionistów starały się powstrzymać nacierające oddziały rosyjskie w czasie ofensywy Brusiłowa w sile 50 tys. żołnierzy. W bitwie tej poległo 2 tys. legionistów. Encyklopedia historii Polski. Dzieje polityczne, t. 1, Warszawa 1991, s. 338.

${ }_{34}$ Prawdopodobnie chodzi o jego pracę w Komisji Przygotowującej Ustawę i Program Szkoły Rycerskiej im. Tadeusza Kościuszki Tymczasowej Rady Stanu, która jednak datowana jest na początek $1918 \mathrm{r}$.

${ }^{35}$ Legun, legionista. Stownik języka polskiego..., t. 4, Warszawa 1962, s. 68.

36 „Nasz pułkownik urodził się zuchem. Jest sługą cara i ojcem dla żołnierzy”. 
Stosowanie takich środków dyscypliny było bodaj na gruncie Legionów całkiem nie do pomyślenia. O niczym podobnym nie słyszałem przez cały czas mojej służby wojskowej.

Zastępcą szefa był w pułku major Trojanowski ${ }^{37}$, o ile mnie pamięć nie myli, królem zwany. Tę krępą, niezgrabną i mało marsową sylwetkę widywało się nie raz na paradach i przeglądach. Zastępczo obejmowali pułk kapitanowie, przez jakiś czas np. w okresie kryzysu przysięgi pamiętam w tej roli kpt. Karaszewicz-Tokarzewskiego ${ }^{38}$, oczy miał przedziwnie ostre, przejmujące, o niemiłym, drapieżnym niemal wyrazie. Umiał on trzymać w ryzie relutonów ${ }^{39}$, choć rezolutny, chwilami bezczelny żołnierz legionowy umiał do oczu skoczyć największemu autorytetowi. W oczach mam scenę, gdy Karaszewicz karci jakiegoś żołnierza, kończąc to groźbą: „Ej, pofruwasz, ty ptaszku, pofruwasz”. Jeszcze te słowa nie przebrzmiały w głuchej, nieprzyjemnej rozbitej jakiejś ciszy, gdy z dalszych szeregów rozległ się ściszony, ale dobrze przez wszystkich i przez adresata słyszany głos: „Ej, popływasz ty Karasiu, popływasz”. Śledztwo nie dało rzecz prosta żadnego rezultatu.

Z pozostałej rzeszy oficerów cztery nazwiska tylko czepiły mi się wyraźniej w pamięci. Wszystkie cztery sławne później na całą Polskę. Sławoj Składkowski $^{40}$. Nie marzył jeszcze naówczas o swej przyszłej karierze politycznej ani o „Strzępach Meldunków” "41; był sobie skromnym lekarzem batalionowym, człowiekiem miłym, prostym, wesołym. Żołnierze przepadali za nim, co nabiera specjalnej wymowy, gdy się zważy, z jaką na ogół pogardą odnosiła się brać

${ }^{37}$ Mieczysław Ryś-Trojanowski (1881-1945), od 1904 r. był członkiem PPS, a za udział w przygotowaniach od zamachu na zastępcę generał-gubernatora Skałona został osadzony w cytadeli warszawskiej. Przed I wojną światową należał do ścisłego kierownictwa Związku Walki Czynnej, jako jeden z pierwszych członków Związku Strzeleckiego zdał egzamin oficerski. W czasie wojny walczył jako oficer w Legionach. W okresie 1916-1917 dowodził 5. pułkiem piechoty Legionów. P. Stawecki, op.cit., s. 339-340.

${ }^{38}$ Michał Tokarzewski-Karaszewicz (1893-1964), studiował na uniwersytetach we Lwowie i Krakowie. Działał w PPS-Frakcji Rewolucyjnej, Związku Walki Czynnej oraz Związku Strzeleckim. W 1913 r. ukończył elitarny kurs oficerski w Stróży. W 1914 r. wstąpił do Legionów i dowodził batalionem w 5. pułku piechoty, a potem był dowódcą tego pułku w stopniu majora..., Ibidem, s. 337-338.

${ }^{39}$ Reluton, żołnierz pobierający żołd (od łac. relutum). Obok leguna drugie popularnie określenie żołnierza Legionów. Stownik języka polskiego ..., t. 7, Warszawa 1965, s. 915.

${ }^{40}$ Felicjan Sławoj Składkowski (1885-1962), w 1904 r. jako student Wydziału Lekarskiego Cesarskiego Uniwersytetu Warszawskiego wziął udział w manifestacji na placu Grzybowskim i został aresztowany, w wyniku czego relegowano go z uczelni. Ukończył studia lekarskie na Uniwersytecie Jagiellońskim w 1911 r. i pracował jako lekarz. Działał też w PPS-Frakcji Rewolucyjnej. W 1914 r. wstąpił do Legionów i potem służył jako naczelny lekarz w 1. i 7. pułku piechoty. W 1. 1916-1917 pełnił taką samą funkcję w 5. pułku piechoty. Miał opinię dobrego lekarza i sprawnego organizatora służby sanitarnej. Z. Landau, Składkowski Sławoj Felicjan, [w:] Polski słownik biograficzny (dalej: PSB), t. 38, Warszawa 1997, s. 193-197.

${ }^{41}$ W 1936 r. w Warszawie wydano jego książkę Strzępy meldunków, która była już jego czwartą pozycją książkową. Ibidem, s. 195. W 1951 r. wszystkie prace Składkowskiego zostały objęte zakazem cenzury i wycofane $\mathrm{z}$ bibliotek. 
leguńska do „łapiduchów”, czyli służby sanitarnej. Ja sam byłem pacjentem kochanego kapitana, gdyż rozchorowałem się na lumbago i pokręcony w czworo przeleżałem parę śmiertelnie długich i nudnych dni w izbie chorych.

Z porucznikiem piątego pułku Kadenem Bandrowskim ${ }^{42}$ nie łączyły mnie już żadne, nawet tak neutralne, lekarskie, jak ze Składkowskim stosunki. Podglądnąłem go ciekawie, jako wchodzącą gwiazdę literatury polskiej, ale nie zbliżyłem się do niego ani razu więcej, niż na to pozwalały regulaminy koszarowe. Był on zresztą i w pułku elementem trochę luźnym. Nie należał bodaj do żadnej kompanii i pętał się przy sztabie pułku, o ile dobrze pomnę, jako adiutant.

Jednym z oficerów naszej kompanii był ppor. Roman Starzyński ${ }^{43}$. Nie lubiliśmy, gdy prowadził ćwiczenie, bo czynił to strasznie nerwowo; jeszcze nie wykonał żadnej komendy, już dawał drugą, mylił się i plątał. Chadzał też z nami na ćwiczenia brat jego, chorąży Starzyński ${ }^{44}$. Nigdy jako szarża udziału nie brał, pamiętam go zawsze na uboczu cichego, szarego, jakby przykurzonego. Nikt w owe czasy nie byłby w stanie przewidzieć, że ten skromny, cichy człek wstrząśnie kiedyś Warszawą i to podwójnie, raz kiedy ją przebudował i do szerszego oddechu sposobił, drugi raz jeszcze potężniej, kiedy jej tak wspaniale broni1 ${ }^{45}$.

${ }^{2}$ Juliusz Kaden Bandrowski, właściwie Juliusz Bandrowski (1885-1944), studiował pianistykę w konserwatoriach w Krakowie, Lwowie, Lipsku i Brukseli. W 1907 r. zajął się publicystyką i był korespondentem prasy krajowej. Działał też w stowarzyszeniach młodzieżowych na emigracji związanych z PPS-Frakcją Rewolucyjną. Oprócz działalności publicystycznej i prelekcyjnej uprawiał literaturę, pisząc pierwsze powieści oraz nowele. W 1914 r. wstąpił do I Brygady Legionów Polskich, zostając adiutantem Józefa Piłsudskiego. Następnie pełnił funkcję oficera werbunkowego oraz kronikarza I Brygady. W 1916 r. został awansowany na chorążego, a od 1 stycznia 1917 r. otrzymał nominację na podporucznika i służył w 5. pułku piechoty Legionów. Dużą popularność przyniosły mu opublikowane w pierwszych latach wojny opowiadania i wspomnienia legionowe. M. Sprusiński, Kaden Bandrowski Juliusz, [w:] PSB, t. 11, Wrocław 1964-1965, s. 401-404.

${ }^{43}$ Roman Starzyński (1890-1938), w 1905 r. za udział w strajku w Szkole Realnej w Łowiczu został z niej relegowany. Następnie uczestniczył w kompletach samokształceniowych. Od 1909 r. studiował polonistykę, historię oraz romanistykę na Uniwersytecie Jagiellońskim. Przed wybuchem wojny obronił pracę doktorską z historii literatury. W 1911 r. wstąpił do Związku Walki Czynnej oraz podjął działalność w Towarzystwie „Strzelec”. W 1914 r. wziął udział w wyprawie kieleckiej strzelców Piłsudskiego. Następnie służył w Oddziale Wywiadowczym 1. pułku piechoty oraz Polskiej Organizacji Wojskowej. Od 1915 r. odbywał służbę w jako dowódca plutonu w 5. pułku piechoty i walczył na Wołyniu. Równocześnie publikował artykuły o tematyce wojskowej oraz relacje z frontu. Z. Kozak, Starzyński Roman, [w:] PSB, t. 42, Warszawa 2003-2004, s. 474-477.

${ }^{44}$ Stefan Starzyński (1893-ok. 1943), młodszy brat Romana. W czasie nauki w gimnazjum brał udział w działalności nielegalnej organizacji niepodległościowej, za co został uwięziony w cytadeli warszawskiej. Ukończył ekonomię na Wyższych Kursach Handlowych Augusta Zielińskiego. W 1914 r. uniknął służby w armii rosyjskiej i wstąpił do Legionów. Pracował jako oficer werbunkowy Departamentu Wojskowego Naczelnego Komitetu Narodowego. Po zwolnieniu w 1915 r. na skutek związków z Piłsudskim trafił do 5. pułku piechoty Legionów i jako dowódca plutonu przeszedł z nim szlak bojowy. Pod koniec 1916 r. został skierowany na kurs oficerski, a po jego ukończeniu powrócił do 5. pułku piechoty. M. M. Drozdowski, Starzyński Stefan, [w:] ibidem, s. 485-493.

${ }^{45}$ Po napaści niemieckiej Stefan Starzyński po odmowie opuszczenia stolicy został mianowany komisarzem cywilnym przy Dowództwie Obrony Warszawy, rozbudował cywilne struktury obrony 
I jeszcze jedno nazwisko. Stefan Rowecki ${ }^{46}$. Widywało się go rzadko, na większych tylko batalionowych zbiórkach. Zostało mi po nim wspomnienie twarzy bladej, jakby dziewczęcej, dziwnie kontrastującej miękkim, zmysłowym wykrojem świeżych, silnie czerwonych warg, z mocnymi, twardo połyskującymi, męskimi oczyma. I znów, kto by się naówczas spodziewał, że ów niepozorny kapitan trząść będzie jako komendant „Grot” całą Warszawą, gdy w ćwierć wieku później ruszy ona do nierównej podziemnej walki ze znienawidzonym okupantem.

Jakoś zaraz w pierwszych dniach mego pobytu trafiły się w pułku większe taktyczne ćwiczenia nocne. Podziwiałem instynkty leśne moich towarzyszy, którzy w czarnej jak atrament nocy poruszali się z pewną swobodą. Jak w biały dzień. Po ćwiczeniach podziwiałem co innego. Niestępioną wrażliwość młodego żołnierza. Zdawałoby się, że w trzecim roku wojaczki i to tak pełnej przygód i wrażeń jak legionowa, nocne ćwiczenia będą dla żołnierzy piłą drewnianą, która prócz nudy nic innego po sobie nie pozostawi. Tymczasem owe ćwiczenia stały się tematem niewyczerpanych gawęd żołnierskich, epizod zaś załamania się lodu na jakimś stawku i skąpanie się kilku żołnierzy żył potem w koszarach tygodniami całymi wznawiany i nicowany bez końca na wszystkie boki aż do znudzenia. Żołnierz, to trochę stare dziecko; raz wysłuchanej bajeczki może słuchać potem setki razy z równym zainteresowaniem.

Bardzo dużo powiedziała mi pierwsza bytność w łaźni żołnierskiej. Dopiero tam z całą plastyką zdałem sobie sprawę z tego, jak krwawa, ale i bujna była żołnierska epopea legionów. Nie było prawie w tym tłumie nagusów jednego żołnierza bez blizny, a były i ciała pokryte całą siecią blizn dużych i małych, dawnych zbielałych już, obok świeżych, tylko co zarosłych, jeszcze różowych. Widok ten miał dla mnie, przyznaję, niezwykłą, niesamowitą wymowę, zwłaszcza na tle zażenowania wynikającego z zestawień z mą własną nietkniętą skórą. Było mi to zresztą jednym więcej dowodem, jak bardzo zżyte z sobą, zgrane, scementowane krwią i wspólnie przeżytym niebezpieczeństwem było legionowe bractwo, do którego ja, rekrut miałem teraz mieć zaszczytne prawo należeć.

Pracowałem ze wszystkich sił, żeby to prawo zdobyć. Nie było mi dane zdobyć go tam, gdzie to zdobędzie byłoby mi przyszło najłatwiej - na polu walki. Legiony zeszły z pola i mimo tułających się tu i ówdzie pogłosek o wymarszu na

stolicy, a swoimi przemówieniami radiowymi podtrzymywał ducha walki u mieszkańców Warszawy. Ibidem, s. 490-491.

${ }^{46}$ Stefan Rowecki (1895-1944), w 1911 r. był organizatorem tajnego zastępu skautowego w Piotrkowie Trybunalskim. W 1912 r, studiował w szkole H. Wawelberga i S. Rotwanda w Warszawie. W 1913 r. wstąpił do Polskich Drużyn Strzeleckich w Warszawie i ukończył kurs podoficerski w Rabce. W lipcu 1914 r. uczestniczył w kursie oficerskim w Nowym Sączu, a pod koniec 1914 r. wstąpił do Legionów Polskich i walczył w I Brygadzie, odbywając wszystkie jej kampanie jako dowódca plutonu, w tym także pod Kostiuchnówką. Pod koniec służby w Legionach pełnił funkcję adiutanta 5. pułku piechoty. T. Szarota, Rowecki Stefan Pawet, [w:] PSB, t. 32, Wrocław 1989-1991, s. $333-338$. 
front, na front ten już wrócić nie miały, pozostawała mi tedy tylko droga pozyskiwania sobie tych serc pokojowymi, ot koszarowymi środkami.

I nie pochlebstwem. Nie było artykułu w równej w legionach pogardzie jak wszelka wazelina, czy to chodziło o stosunek z równym czy z wyższym. Nosy miały leguny na ten zapach wyostrzone i czułe niesłychanie, i najmniejszy faux $\operatorname{pas}^{47} \mathrm{z}$ mej strony byłby mnie z kretesem zgubił. Na szczęście nigdy nie miałem i nie mam $\mathrm{w}$ tej dziedzinie żadnego grzechu $\mathrm{z}$ rachunku sumienia.

Nie przekupstwem, nie pochlebstwem, więc czym? Chyba tym, czego odurzający zapach bił ku mnie od tego młodego lasu - prostotą.

Zacząłem podbijanie serc koleżeńskich od moich najbliższych sąsiadów z pryczy. Los dał mi tu dwóch ludzi, z którymi złączyła mnie z czasem niezwykle mocna przyjaźń sięgająca poza legiony; ostatnie kontakty przetrwały nawet drugą wojnę.

Jasiek Szram ${ }^{48}$ ze Szramowizny ${ }^{49}$ pod Skierbieszowem ${ }^{50}$, Marek Lipszyc ${ }^{51}$ z Częstochowy. Trudno było o większy kontrast charakterów, umysłowości, typów fizycznych, usposobień. Jeden chłop z chłopa, pradziada, rozrośnięty jak dębczak, wysoki, jasnowłosy, niebieskooki, drugi Żydziak z jakiegoś wciśniętego w najgłębszą częstochowską biedę proletariatu, czarny pokurcz, poharatany i postrzelany jak sito, szczupły z zapadniętą piersią, z twarzą i czarnymi palącymi oczami fanatyka. Jeden równy, spokojny, pogodny, stale uśmiechnięty do życia i ludzi, drugi pokręcony psychicznie, pełen chandr ${ }^{52}$, depresji, załamań i wyborów życiowych. Od znajomości przeszliśmy z czasem do wspólnej pracy tj. nauki, której udzieliłem im obu w zakresie szkoły powszechnej. I tu wyszły na jaw dalsze czy głębsze różnice. Jasiek, chłopak niepospolicie inteligentny i zdolny, chwytał w lot wszystko, co mu się choćby przez szparę pokazało. Marek był nieprawdopodobnie tępy i nie mógł sobie dać rady z najprostszymi arkanami arytmetyki czy ortografii. Los poskąpiwszy mu zdolności nie poskąpił mu, niestety, zainteresowania i zapału do nauki, i oto biedny Marek trawił długie, wolne od ćwiczeń godziny na zaciekłe, desperackie wpychanie sobie do głowy tego, co tam dobrowolnie samo wejść nie chciało. Oczywiście bez powodzenia. Jakby mu tego było jeszcze mało, a biednym nieporadnym swym umysłem porywał się

${ }^{47}$ Faux-pas, niestosowność, gafa, wpadka. W. Kopaliński, Słownik wyrazów obcych i zwrotów obcojęzycznych, Warszawa 1985, s. 136.

48 Jan Szram, skądinąd nieznany.

49 Szramowizna, miejscowość niezidentyfikowana. Obecnie nie istnieje.

50 Skierbieszów, położony na południowy-wschód od Lublina i oddalony od niego o ok. $80 \mathrm{~km}$. Obecnie wieś i centrum gminy w pow. zamojskim i woj. lubelskim. J. Niedźwiedź. Leksykon historyczny miejscowości dawnego województwa zamojskiego, Zamość 2003, s. 457-584

${ }_{51}$ Markus Lipszyc, szeregowy 1. kompanii 5. pułku III Brygady Legionów. Lista podoficerów i żołnierzy wywiezionych do obozu w Szczypiornie 16 lipca 1917 r. poz. 14, s. 114, http://caw.wp.mil. pl/plik/file/legiony polskie/i 120 1/I 120 1 $13 . p d f$ [dostęp: 21.05.2018]

${ }^{52}$ Chandra, stan przygnębienia, apatii, zniechęcenia do życia, złe samopoczucie. Słownik wyrazów obcych..., s. 109. 
na coraz zawilsze medytacje i analizy, na zawrotne abstrakcje, na zagadnienie śmierci, życia zagrobowego, szczęścia itp.

Niedługo po moim przybyciu do koszar przyszło przedwiośnie, zaczęło nas nosić po okolicznych polach i lasach. Chadzaliśmy stale we trójkę, ja w środku, Marek z jednej, Jasiek z drugiej strony, i prowadziliśmy nieskończone spory i dyskusje. Marek je zwykle wszczynał, borykając się ciężko już z samym sformułowaniem zagadnienia, tonąc zaś zupełnie, kiedy przyszło je rozwiązywać. Dla Jaśka wszystko było jasne, proste zrozumiałe; wszystkie tak krwawo, mozolnie przez Marka wypocone dylematy nie tyle rozwiązywał, co rozcinał swym trzeźwym, jasnym chłopskim rozumem, swoimi lapidarnymi, kapitalnymi nieraz powiedzeniami. Jakże mi żal, że ich nie notowałem; pamięć moja zagubiła je wszystkie, co do jednego.

Marek przeżywał owe zagadnienie wieczności, grzechu czy sprawiedliwości społecznej nie tylko intelektualnie, ale i uczuciowo, wżerał się w nie całą jaźnią, gryzł, trawił dniami i nocami. Tak, nocami; zdarzało się i w nocy, że Lipszyc zorientowawszy się, że nie śpię, zwracał się do mnie z gorącym szeptem: - Obywatelu profesorze, co to jest prawda? Albo wiekuiście niezagojone, bolesne jego pytanie - co jest w życiu ważniejsze: siła czy dobroć? I obywatel profesor musiał nieraz robić karkołomne łamańce, aby nadążyć za zygzakami myśli tego filozofa-tępaka, by nie zniechęcić oczu patrzących we mnie z takim głęboko zaufaniem, nie zerwać nici przyjaźni, które w tych dyskusjach wiązały coraz ściślej naszą sitwę. Jakże było mi przykre, gdy musiałem przechylić się na stronę prostej, ale przeważnie nieodpartej argumentacji jaśkowej.

Były w nich cechy pokrewne, sprowadzające te dwa tak rozbieżne typy do wspólnego mianownika. Obaj ponoć ludzie ogromnej odwagi, rzecz znana mi tylko z opowiadań, bo ich w ogniu nie widziałem, ale znajdująca bezpośrednie potwierdzenie w bliznach, które na nich w łaźni oglądałem. Obaj szczerzy i impulsywni, uczuciowi, natury z gruntu dobre, wrażliwe na niedolę ludzką, ofiarne i hojne. Szram rozdawał wszystko, co miał z zażenowanym cichym wdziękiem, prosto jak duże dziecko, bez żadnej pozy; Marek z pewnym histeryzującym nieco gestem.

Moi dwaj adiutanci, jak ich później w kompanii nazywano, czy sitwesi ${ }^{53}$, byli mi i wtedy i później najbliżsi i najciekawsi, ale ileż takich ciekawych typów chodziło wtedy po koszarach czy podwórzu koszarowym piątego pułku. Ogromna rozpiętość społeczna od obywatelskich synów do najniższych pokładów proletariatu, czy kulturalna od tępaka Lipszyca do umysłowości Tytusa Filipowicza, późniejszego ambasadora polskiego w USA, na ówczas kaprala w naszej kompanii. Koledzy żołnierze wyprorokowali mu jego przyszłe stanowisko, bo, Bóg raczy widzieć, skąd przylgnęło do niego już wtedy, w r. 1917, przezwisko „Ambasador”.

\footnotetext{
${ }^{53}$ Sitwesi, wspólnicy (od sitwa - spółka). Ibidem, s. 683.
} 
Snują mi się przed uśmiechniętymi oczyma postacie moich legunów. Nazwisk już nie pamiętam, chyba wyjątkowo wychyli się z cienia niepamięci marsowa, spokojna, męska twarz kaprala Jana Trzaski Sokołowskiego ${ }^{54}$, albo sylwetka siłacza nie tylko w fizycznym, ale i psychicznym tego słowa znaczeniu, Józka Staneckieg $0^{55}$. Robociarz z Zagłębia ${ }^{56}$, chłop wysoki, wspaniale zbudowany, o cudownej, niewzruszonej równowadze mięśni, nerwów, duszy. Skończony pełny typ człowieka, jeden z filarów kompanii, gdy przyszły na nią ciężkie kryzysowe czasy przysięgi, Szczypiórna ${ }^{57} \ldots$

Kiedy o nim myślę, staje mi zawsze w oczach inny obraz. Już byłem wtedy żonaty, dzieciaty i z całą rodziną wybraliśmy się kiedyś do Zagłębia na zwiedzanie kopalni. Wielkie zmodernizowane zakłady, olbrzymia hala, nowoczesna instalacja, maszyny... W jednej z tych hal na wysokim podium stał robotnik atletycznej budowy do pasa nagi. Przed sobą miał wysoką tablicę, na której nieustannie przesuwały się to $\mathrm{w}$ górę to $\mathrm{w}$ dół jakieś światełka. W ręku miał dźwignię, którą manipulował zdecydowanymi równymi ruchami. W ruchach tych, w wyrazie twarzy, w całej tej sylwetce było tyle skupienia, napięcia nerwów, a jednocześnie opanowania i kamiennego spokoju, że stanęliśmy wszyscy jak urzeczeni. Objaśniono nas, że ten człowiek kieruje dźwigami w całej kopalni i że jedna chwila roztargnienia, jeden fałszywy ruch ręką wystarczy, by spowodować katastrofę. Pomyślałem sobie, że dobrze musi być płatny ten robotnik, że musi mieć głowę zupełnie wolną od kłopotów, by z takim spokojem poruszać swoją dźwignią. Długo stałem, nie mogąc oderwać oczu od tego widoku. Istny symbol skupionej, wytężonej pracy ludzkiej. No i nie wiem, czy wtedy już, czy przez późniejsze jakieś asocjacje ${ }^{58}$ myślowe nawiązałem $\mathrm{z}$ tym wspomnieniem Staneckiego. Ten by się tu nadał. Temu by można ową dźwignię z całym spokojem w ręce oddać.

\footnotetext{
${ }^{54}$ Jan Trzaska Sokołowski, kapral 2. kompanii 5. pułku III Brygady Legionów. Lista podoficerów i żołnierzy wywiezionych do obozu w Szczypiornie 16 lipca 1917 r. poz. 4, s. 114, http://caw.wp.mil. pl/plik/file/legiony polskie/i_120_1/I_120_1_13.pdf [dostęp: 21.05.2018].

55 Józef Stanecki, starszy żołnierz 1. kompanii 5. pułku III Brygady Legionów. Lista podoficerów i żołnierzy wywiezionych do obozu w Szczypiornie 16 lipca 1917 r. poz. 10, s. 114, http://caw.wp.mil. pl/plik/file/legiony_polskie/i_120_1/I_120_1_13.pdf [dostęp: 21.05.2018].

${ }^{56}$ Zagłębie Dąbrowskie, region historyczno-geograficzny leżący na pograniczu Śląska i Małopolski od 1867 r. należący do pow. będzińskiego obejmujący stare i nowe osady oraz miasta: Sosnowiec, Dąbrowa Górnicza, Będzin, Czeladź, Grodziec, Siewierz, Zawiercie, Myszków. Krótko (1795-1807) należał do Prus, a potem pozostawał już w zaborze rosyjskim aż do $1915 \mathrm{r}$. Na jego terenie występują złoża węgla, rudy żelaza, galmanu i wapienia. Zagłębie Dąbrowskie w czasach zaborów $i$ walk o niepodległość (do roku 1918), red. J. Walczak, Sosnowiec 2004, s. 5-6.

${ }^{57}$ W Szczypiornie znajdował się obóz internowania żołnierzy i podoficerów Legionów Polskich w okresie od lipca do grudnia 1917 r. K. Bąbiński, Zarys historii wojennej 5-go putku piechoty Legionów, Warszawa 1929, s. 16. Od 1976 r. Szczypiorno stanowi dzielnicę Kalisza.

${ }^{58}$ Asocjacja, połączenie, związek. Stownik wyrazów obcych..., s. 51.
} 
Temu człowiekowi zresztą zawdzięczam najpiękniejszą chwilę w mojej służbie wojskowej, a niewiele brakuje, można by powiedzieć - jedną z najpiękniejszych chwil w życiu.

Jest już lato. Już mam za sobą pół roku służby w kompanii, już stopniały styczniowe lody mego koleżeńskiego chrztu. Jest jakiś marsz. Jako najwyższy w kompanii idę w pierwszej czwórce, mając jako zwykłych w niej sąsiadów Szrama z jednej, Staneckiego z drugiej strony. Lipszyc jako znacznie niższy chadzał zawsze w środku kompanii. Rozmowa, której tenoru ${ }^{59}$ już nie pamiętam, a której wynikiem było, że miałem się podjąć jakiejś reprezentacji kompanii. Funkcja zaszczytna. Zaczynam się wymawiać. Ja? Homo novus ${ }^{60}$ w kompanii, „rekruckie ucho” - nie - to nie dla mnie.

A Stanecki nagle, jak nie fuknie na mnie:

„Co wy, Konarski. Wyście są z wiary”.

Jeśli się kiedy nad kim niebo otwiera, to otworzyło się ono wówczas nade mną i do tej chwili, jak sobie to przypomnę, to mnie wzruszenie chwyta za gardło. Wyście są $\mathrm{z}$ wiary - nominacja na wiarusa podpisana przez najtęższego z wiarusów. Nie wiem, jakie uczucia przeżywa człek, któremu na polu bitwy przypinają do piersi Virtuti Militari, bo mi tego szczęścia nie sądzone było zaznać, ale, że moja radość w owym marszu była czymś pokrewnym tym uczuciom, to pewno. Miewałem później odznaczenia. Niejedno. Nawet bym ich wymienić nie mógł, tak mi one spełzły z pamięci, tak nic, dosłownie nic mi $\mathrm{z}$ nich nie pozostało, ale tamto przeżycie noszę w duszy jak klejnot bez ceny. Wyście są z wiary.

Roboty w pułku mieliśmy niewiele, nudów za to co niemiara.

Motywem czy pozorem odejścia pułku z frontu na tyły było jego przeszkolenie wojskowe. $\mathrm{Z}$ austriackiego drill' ${ }^{61}$ mieliśmy przejść na niemiecki. $\mathrm{W}$ gruncie rzeczy nie przyswoiliśmy sobie żadnego i zachowaliśmy własny leguński, zanarchizowany, jak twierdzili nasi instruktorzy Niemcy, polski, jak twierdziliśmy my, regime ${ }^{62}$ czy fason. Oczywiście pewne pozory trzeba było zachować, tłukł wtedy pułk musztrę pruską, jak poprzednio tłukł musztrę austriacką, ale znudzony nią śmiertelnie żołnierz obijał [się] jak mógł i postępy czynił minimalne. Rola instruktorów była w tych warunkach nie do pozazdroszczenia. Cała ich systematyczność, wytrwałość, gorliwość rozbijała się, a raczej więzła w jałowej nieproduktywnej nudzie. Personel instruktorski dobrany był dobrze, ludzie przyzwoici, taktowni, zatargów z nimi nie było, prawda, że znali oni mores ${ }^{63}$ przed zwartą, zdecydowaną a solidarną atmosferą leguńską i nie próbowali nigdy przełamywać jej środkami ostrzejszej dyscypliny wojskowej. Miarą, jak dalece

\footnotetext{
59 Tenor, treść, zawartość. Ibidem, s. 753.

${ }^{60}$ Homo novus, nowicjusz, parweniusz. W. Kopaliński, op.cit., s. 177.

${ }^{61}$ Dryl, ostra dyscyplina, ślepe posłuszeństwo. Słownik wyrazów obcych ..., s. 160.

${ }^{62}$ Régime - reżim, rządy, władza, porządek prawny, ustrój. W. Kopaliński, op.cit., s. 368.

${ }^{63}$ Mores, rygor, karność, respekt. Slownik wyrazów obcych ..., s. 492.
} 
traktowano nas w rękawiczkach, może być drobny, ale charakterystyczny fakt, jaki spotkał mnie kiedyś na przeglądzie kompanii. Stawiłem się nań nieogolony. Instruktor zauważył to, ale zamiast mnie zrąbać za ten nieporządek, komunikuje mi uprzejmie, że jeśli chcę zapuścić brodę, to muszę mieć pozwolenie od komendanta kompanii. Stwierdzić zresztą należy, że pewną dozę tej kurtuazji przypisać należy owemu zakłopotanemu protekcjonalizmowi w stosunku do mojej profesorskiej osoby, o którym wspomniałem przy opisie pierwszych moich kroków na terenie koszar i którego mimo wysiłków z mej strony nie zdołałem aż do końca wyeliminować z mego stosunku do władz wojskowych czy to polskich, czy - jak w dawnym wypadku - nawet niemieckich.

Ratował się człek przed tą nudą jak mógł. Nieliczni kolejni wybrańcy losu uzyskiwali urlopy i wyjeżdżali z pułku. W niedzielę i święta, kto żył, szedł do Ostrowi, miasta obfitującego we wszelkie mniej lub więcej zakazane rozkosze z podłym roztrzęsionym kinem na czele. Kto nie dostał przepustki, szedł na pociechę do knajpy, w której królowała Gołda - patrz „Chłopięce lata” pamiętni$\mathrm{ka}^{64}$ - albo jak my z Jaśkiem i Markiem zazwyczaj w świat.

Chodziłem i ja do Gołdy na wcale przyjazną pogawędkę. Traktowała mnie ona trochę inaczej niż moich kolegów legunów. Może dlatego, że mimo jej królewskiej urody nie kochałem się w niej i stosunek mój z nią postawiłem od razu nie na stopie flirtu, ale takiej ni to sąsiedzkiej, ni to koleżeńskiej zażyłości. Tak coś jak z tymi dziewczętami z szóstej klasy u Walickiej ${ }^{65}$. Może nie tyle tak, że z Gołdą żadnego dokazywania nie było. Za smutne miała oczy. Ale gwarzyło się z nią miło, a trzymane za mordę przez Gołdę moje w ząbek czesane leguny komilitony ${ }^{66}$ musiały spokojnie przyglądać się i tolerować, jak ich królewna prowadzi z profesorem przyjazną gawędę. Albo jak go np. uczy węgierskiej piosenki, słowo po słowie:

Sei passuniok kuryzalok. Sei ... passuniok ...

Hej, ta piosenka. Ma ona już całą krótką, ale kolorową historię. Nie mogę tu o niej nie wspomnieć, za bardzo mnie to tentuje. Piosenkę tę słyszała Gołda gdzieś na froncie, jeszcze pod Baranowiczami ${ }^{67}$, gdzie stacjonowały wówczas jakieś węgierskie wojska ${ }^{68}$. Nauczyła się nie tylko melodii, ale i słów, jak papuga nie rozumiejąc ani słowa. Od niej znów jak papuga, nie rozumiejąc ani słowa,

\footnotetext{
${ }^{64}$ Chodzi o drugi rozdział wspomnień „Chłopackie lata”, w którym Konarski opisał kantynę Żyda Kobryńskiego i jego córkę Gołdę (K. Konarski, op.cit., s. 35-36).

${ }^{65}$ Autor nawiązuje do swojej krótkotrwałej pracy w charakterze nauczyciela historii w warszawskim prywatnym gimnazjum Antoniny Walickiej w latach 1914-1915. Ibidem, s. 186-187.

${ }^{66}$ Komiliton, towarzysz broni, kolega szkolny. Słownik wyrazów obcych..., s. 370.

${ }^{67}$ Baranowicze, wieś w pow. nowogródzkim w gub. mińskiej oraz węzeł kolejowy o znaczeniu strategicznym. Obok niej znajdowała się stacja kolejowa na trasie z Brześcia do Moskwy. SGKP, t. 1, Warszawa 1880, s. 104.

${ }^{68}$ W czerwcu i lipcu 1916 r. doszło do krwawej bitwy pod Baranowiczami w czasie rosyjskiej ofensywy 4. armii gen. A.F. Rahozy, wchodzącej w skład Frontu Zachodniego, na pozycje 9. armii niemieckiej dowodzonej przez ks. feldmarszałka Leopolda Bawarskiego. W jej składzie znajdował
} 
nauczyłem się ja. Bardzo melodyjna, urozmaicona zagadkową niezrozumiałą grą słów, weszła ona do mego stałego repertuaru.

Kiedyś w parę lat później zgadało się o tym w licznym towarzystwie na jakimś warszawskim fajfie. Okazało się, że jedna z panien zna język węgierski i rada by usłyszeć piosenkę. Ostrzegam, że nie rozumiem z niej ani słowa, nie znam tedy jej treści, od której mogą zwiędnąć panieńskie uszy.

Niech pan zaśpiewa.

Ha. Volenti non fit iniuria, jak mówi prawo rzymskie. Chcącemu nie dzieje się krzywda. Chcesz, babo, to słuchaj. Zaśpiewałem.

Nie dośpiewałem jeszcze i dwóch wierszy, gdy moja panna w pons ${ }^{69}$.

Niech pan nie śpiewa, niech pan przestanie.

Historia piosenki na tym się nie kończy. Minęło znów lat kilkoro, tak coś około dwudziestu.

Są lasy chojnowskie ${ }^{70}$ pod Warszawą, a w nich oddziałek AK. Wrzesień 1944. Idzie sobie leśną ścieżką żołnierz AK. Niedaleko jego plutonu stacjonuje oddział węgierski, wysłany przez Niemców na tropienie „polskich bandytów”. Węgrzy mają co lepszego do roboty, niż tropić naszych chłopców, toteż stosunki między oddziałami układają się na gruncie przyjaznej życzliwej neutralności. Bliższej przyjaźni stają na przeszkodzie tylko trudności językowe.

Idzie sobie tedy ścieżką leśną żołnierz AK nazywa się Stanisław Konarski ${ }^{71}$. Nuci nauczoną od ojca piosenkę: Sei passuniok kuryzalok...

Mijają się z oficerem węgierskim. Węgier staje na dźwięk piosenki jak wryty, zatrzymuje żołnierza i jakąś połamaną w kawałki niemczyzną bada, skąd ów żołnierz zna tę piosenkę. $Z$ rozmowy wynikła krótka przelotna znajomość czy przyjaźń polsko-węgierska, która między innymi doprowadziła do skorygowania tekstu zniekształconego przez trzykrotny już nieświadomy rzeczy przekaz. Dziś śpiewa ją Stach poprawnie. I zna treść, ale mi jej powtórzyć nie chce. Musi tam być niezgorszy pieprz.

No i czy nie miło pachnie piosenka. Jak ta łąka w czerwcu. Czyż można nad takim wspomnieniem, choć ono jest drobne i nieznaczące, przejść obojętnie do porządku dziennego, pominąć je, zapomnieć.

Piosenka się skończyła, wróćmy do Ostrowi, albo gwoli rozmaitości do Trynos $^{72}$, wioski położonej o parę kilometrów od koszar, dokąd nas zapędziła któraś z naszych łazęg. Wiedziałem, że właścicielami jej są Brudzińscy, miałem tedy

\footnotetext{
się XII korpus austro-węgierski. J. Rubacha, Korpus Landwehry w bojach o Baranowicze latem 1916, „Słupskie Studia Historyczne” 2010, nr 16, s. 73-83.

${ }_{69}$ Pons, kolor jasno-czerwony. J. Karłowicz, A. Kryński, W. Niedźwiedzki, op.cit., t. 4, Warszawa 1908, s. 599.

${ }^{70}$ Chojnów, wieś i gmina w par. Jazgarzew i pow. grójeckim. SGKP, t. 1, Warszawa 1880, s. 622.

${ }^{71}$ Stanisław Konarski, syn Kazimierza.

72 Trynosy, wieś w pow. ostrowskim i w gm. Komorowo w par. Jelonki. SGKP, t. 12, Warszawa 1892, s. 533.
} 
zamiar spenetrować czy nie są to krewni mego rektora ${ }^{73}$, z którym łączyły mnie bardzo miłe powiedzmy koleżeńskie (pediatria) stosunki. Wchodzimy tedy do dworu, ja z moimi adiutantami, meldujemy się do pana dziedzica. Proszą nas do saloniku $i$ tu wychodzi do nas starszy pan, typowy żywcem wycięty $z$ encyklopedii staropolskiej szlagon ${ }^{74}$ i przybrawszy oblicze w lodowate dekoracje zapytuje jeszcze bardziej lodowatym głosem, czemu ma przypisać zaszczyt odwiedzenia przez nas jego progów.

Aha. Już wiem, rozumiem. Zaraz będą pruskie pachołki i tym podobne. Jeśli tu do nich nie dojdzie, to tylko przez wzgląd na prawa gościnności, które nie pozwalają gospodarzowi wybuchnąć gorzką czy jadowitą tyradą na temat naszego odszczepieństwa, zdrady głównej i całego splotu innych zbrodni. Jużbyśmy zresztą może woleli takie rozwiązanie niż tę lodowatą skorupę, która jest w tej chwili tak niezdarnie przyklejona do poczciwej w zasadzie szlagońskiej gęby, tak komicznie odstaje od niej, że człek sam nie wie, co robić, czy wyjść trzasnąwszy drzwiami, czy się panu dziedzicowi w nos z jego nabzdyczonej miny roześmiać.

Nie zrobiliśmy ani tego, ani tego, a w godzinę później siedzieliśmy już przy jakimś wspaniałym podwieczorku, zakrapianym, choć to nie pora, węgrzynem i ... śpiewaliśmy leguńskie piosenki jedna za drugą. Domownicy podśpiewywali z nami, a pan dziedzic, choć nie podśpiewywał, ale przyglądał się nam zwilgłymi wyraźnie oczyma. Lód zdążył już stajać i wypływał oto łzami. Uczciwymi, czystymi polskimi łzami.

I rektorowi Brudzińskiemu się przysłużyłem, bośmy mu stryja skaptowali dla aktywizmu zwykłą leguńska piosenką. Bywałem w czasie mej służby wojskowej nieraz w pokrewnych sytuacjach, ale tak piorunującą propagandę widziałem pierwszy raz w życiu. Wróciliśmy do koszar już nie piechotą, ale końmi obdarowani wszystkim, czym wieś mogła obdarować żołnierza, zobligowani do dalszych wizyt. Trwały te stosunki do późnej wiosny, to jest do czasu wymarszu naszego z Ostrowi.

Między innymi pomogły mi Trynosy bardzo wydatnie w akcji aprowizacyjnej, jaką próbowałem zapoczątkować w naszej kompanii. Żywiono nas nędznie, przednówek dawał się coraz bardziej we znaki, dobrze pamiętam zmarznięte ziemniaki przeciekające dosłownie przez palce przy obieraniu ich, a obrzydliwie

${ }^{73}$ Józef Polikarp Brudziński (1874-1917), lekarz pediatra i neurolog. Studiował na uniwersytetach w Dorpacie i Moskwie. W 1910 r. organizował nowy szpital im. Karola i Marii w Warszawie, który powstał z fundacji prywatnej i został jego naczelnym lekarzem. W 1915 r. został mianowany przez gubernatora Hansa von Beslera rektorem Uniwersytetu Warszawskiego i tę funkcję pełnił niemal do śmierci. Był współzałożycielem Polskiego Towarzystwa Pediatrycznego oraz „Przeglądu Pediatrycznego”. Opisał wiele objawów zapalenia opon mózgowo-rdzeniowych (objawy Brudzińskiego). M. Handelsman, Brudziński Polikarp Józef, [w:] PSB, t. 3, Kraków 1937, s. 11-12.

${ }^{74}$ Szlagon, niewykształcony szlachcic mieszkający na prowincji, hreczkosiej. J. Karłowicz, A. Kryński, W. Niedźwiedzki, op.cit., t. 6, Warszawa 1915, s. 631. 
słodkie później w cienkich wasserzupkach ${ }^{75}$, jakie nam wydzielano na obiad. Tłuszczu nie widywaliśmy całymi tygodniami. Przyszło mi na myśl zorganizować naszym własnym zbiorowym przemysłem jakieś dożywianie. Zrobiliśmy w plutonie składkę, starczyło na zakup nabiału, ziemniaków przysłały po śmiesznej cenie Trynosy, wystaraliśmy się o wanienkę do mycia ziemniaków, która awansowała na kociołek, opału dostarczył jakiś niedołamany do szczętu płot koszarowy, ustaliliśmy dyżury kucharskie i w rezultacie mieliśmy na śniadanie przez parę tygodni dodatkowe porcje zabielanej wcale nieźle mlekiem kartoflanki. Czy akcja ta rozszerzyła się na inne plutony nie pamiętam, wiem tylko, że władze patrzyły na te nasze pitraszenia przez życzliwe palce.

W pełnej beztrosce psychicznej, jaką może dać tylko zawód żołnierza, zrzucałem z pleców górę po górze, jakie mi narosły na profesorskiej katedrze (w brulionie słowo to było napisane niewyraźnie i omal nie zapisałem - katordze). Jak tam starzałem się z każdym miesiącem o rok, tak tutaj młodniałem z zastraszającą szybkością, asymilując się zupełnie z tą rozdokazywaną gromadą, żeby nie powiedzieć - bandą starych dzieciaków. Obieranie ziemniaków czy choćby kunszty chwytów karabinowych były o całe niebo łatwiejsze od analiz i syntez historycznych, a mało zaszczytne zresztą poczucie czy rozumowanie, że tam ktoś na górze poweźmie za mnie decyzję, co do mego postępowania, a mnie nie pozostaje nic innego niż słuchać wydanych mi rozkazów, było rozkosznym wypoczynkiem po szarpaninach nerwowych mej sali wykładowej czy zwłaszcza seminaryjnej. Stan ten nie mógł zresztą trwać zbyt długo. Nadchodziły czasy, kiedy okoliczności zewnętrzne zmuszały nas do powzięcia własnych czy to indywidualnych czy zbiorowych decyzji. Nadchodziły czasy kryzysu przysięgi.

Pierwszym wstrząsem pozbawionym zresztą zdaje się zupełnie motywów politycznych było przesiedlenie nas z Ostrowi do Różana ${ }^{76}$. Klęliśmy, na czym świat stoi. Na front? I owszem, czemu nie, byliśmy za nim stęsknieni wszyscy, nie wyłączając i mnie, który go wprawdzie nigdy nie oglądał, ale tym goręcej pragnął zobaczyć. Ale inny garnizon? Te same nudy w nowych obcych kątach, gdy te nasze stare już się utarły, już nie uwierają. Ten i ów zdążył się już zaaklimatyzować, porobić znajomości, znaleźć swoje Trynosy czy swoją dziewczynę. Słowem ruszaliśmy z naszego barłogu bardzo niechętnie.

Rozkaz to rozkaz. Dyskusja była trudna. Pewnego tedy skwarnego, majowego czy czerwcowego poranku uszykowano na szosie cały pułk. Długi tasiemiec kolumn pieszych, za nimi bodaj jeszcze dłuższy taborów. Wyroiły się z żydowskich sklepików na szosę wszystkie primadonny komorowskiego półświatka, krążą w powietrzu soczyste dialogi. Wreszcie gotowe, ruszamy. Po chwili znikły nam z oczu koszary. Dla pułku zapadał w przeszłość jeden więcej z niezliczonej

\footnotetext{
${ }^{75}$ Wasserzupka, wodnista zupa. W. Kopaliński, op.cit., s. 449.

${ }^{76}$ Różan, osada miejska na Narwią z kościołem parafialnym w pow. makowskim i w gm. Wieluń. SGKP, t. 9, Warszawa 1888, s. 851. Obecnie w pow. makowskim i woj. mazowieckim.
} 
liczby etapów, dla mnie jeden z najciekawszych rozdziałów życia, któremu na imię - żołnierski chrzest koleżeński.

Przemarsz do Różana trwał cały dzień, a skwar uczynił nam tę drogę niesłychanie męczącą. Dowlekliśmy się ledwie żywi, by się dowiedzieć, że lokować mamy się nie jak Bóg przykazał w koszarach, ale w nader nieponętnych bardzo, wilgotnych kazamatach fortu. Na razie byliśmy wszyscy zbyt pomęczeni, żeby protestować, ale na drugi dzień wszczęło niesforne bractwo legionowe mocny huczek. Protest ten jak tyle innych leguńskich protestów rozszedł się po kościach i po paru dniach poszedł całkowicie w zapomnienie.

W niedługim zresztą czasie przyszły wypadki, wobec których ważna skądinąd sprawa zaciekających murów koszarowych utraciła całą swą aktualność. Nadchodziły czasy przysięgi.

Dla wypadków, które rozegrały się na terenie pułku w połowie lipca $1916 \mathrm{r} .{ }^{77}$ zachował mi się raptularzyk pisany na świeżo dzień po dniu tak, że część pamiętnika pisana prawie pod dyktando owego raptularza, może być traktowana jako źródło historyczne spisane przez naocznego świadka. Inna rzecz, że świadek świadomie i celowo niewychylający nosa z szeregu widział tylko to, co widział ów szereg, niemniej jednak i także oświetlenie owych faktów może nie być bez interesu dla przyszłego historyka owych dni.

Raptularzykowi temu oddaję tedy głos z tym, że zmiany wprowadzone do niego mają raczej redakcyjny i stylistyczny charakter. Ten i ów szczegół podany zbyt lakonicznie i wskutek tego dziś już dla mnie samego niezrozumiały, wypadło w tekście opuścić.

Piątek 6 lipca. Odczytanie rozkazu dziennego zawierającego rozporządzenie Tymczasowej Rady Stanu i złożeniu przysięgi.

Sobota 7 lipca. W południe posiedzenie oficerów w Kasynie i jednomyślna uchwała odmówienia złożenia przysięgi. Zawiadomienie o tym żołnierzy. Do Warszawy wyjeżdża major Trojanowski. Pogłoski o aresztowaniu go i o wezwaniu do Warszawy Rokity ${ }^{78}$ i Olszyny ${ }^{79}$. Popłoch w pułku.

77 Tak w dokumencie. Powinno być: 1917 r.

78 Włodzimierz Marian Maxymowicz, ps. „Rokita” „Raczyński” (później Maxymowicz-Raczyński) (1891-1938), był członkiem Polskich Drużyn Strzeleckich. W 1914 r. został zmobilizowany do armii austriackiej, ale ranny zbiegł do Legionów i przybrał nazwisko Raczyński. Dowodził w nich kompanią, batalionem, w tym także w 5. pułku piechoty. M. Krwawicz, Maxymowicz-Raczyński Włodzimierz Marian, [w:] PSB, t. 20, Wrocław 1975, s. 269-270.

79 Józef Olszyna-Wilczyński (1890-1939) (pierwotne nazwisko Wilczyński), studiował na Wydziale Budownictwa Lądowego na Politechnice Lwowskiej. Podczas studiów odbył służbę wojskową w armii austriackiej i ukończył szkołę oficerów rezerwy. Od 1912 r. był też związany z Polskimi Drużynami Strzeleckimi. W 1914 r. zmobilizowany do armii austriackiej. Ranny uciekł ze szpitala do Legionów i służył jako dowódca kompanii oraz batalionu w 5. pułku piechoty w stopniu. W 1916 r. leczył się w szpitalach w Zakopanem i Krakowie. Następnie w stopniu kapitana do końca września 1917 r. dowodził batalionem w 5. pułku piechoty. M. Krwawicz, Olszyna-Wilczyński Józef Konstanty, [w:] PSB, t. 24, Wrocław 1979, s. 52-53. 
Zebranie w sprawie przysięgi. Przyjęcie do wiadomości uchwał rady oficerskiej. Nie mieli czasu porozumieć się z nami, liczą na jednomyślność z nimi. Drugie zebranie wieczorem. Doskonały nastrój wśród żołnierzy.

W rozkazie dziennym zbiórka kompanii reprezentacyjnej na siódmą rano. Wieczorem czy też rano odwołanie. O godzinie drugiej po południu nowy rozkaz stawienia kompanii. Od nas idzie siedmiu ludzi, prowadzić ma Poraj ${ }^{80}$. Pertraktacje co do formy odmówienia. Zebranie w tej sprawie w gorączkowym tempie, bo już prawie w chwili zbiórki.

Ostateczna forma: delegaci od batalionów pójdą do komendantów, oświadczając im, że kompanie ludzi nie wydadzą. U nas zbiórka formalnie się odbyła, odwołana w chwili, gdy delegat wrócił od kapitana. Podobno kapitanowie służbowo zameldowali Żymierskiemu ${ }^{81}$, że ludzi nie dadzą, co spowodowało aresztowanie kapitanów.

Niedziela 8 VII. Dymisja Żymierskiego. Kancelaria zawieszona. Żymierski wyjeżdża do Serocka ${ }^{82}$.

Poniedziałek 9 VII. Przez cały krytyczny tydzień przysięgi nieustanne ćwiczenia u Niemców w rzucaniu granatów ręcznych; kanonada salwami i pojedyncza. Wśród ludności (Jabłonna ${ }^{83}$ ) mało znajdujące wiary pogłoski, że to już bitwa $\mathrm{z}$ nami. W koszarach rozlepione afisze przestrzegające przed szpiegostwem, nawoływania do wystąpienia kupą w razie oddzielnych zbiórek królewiaków i Galicjan. Pierwsza wiadomość o przysiędze i pogłoski o opozycji czynnej czwartego pułku.

Wtorek 10 VII. Moja kordegarda. Nastroje podniecone. Patrole nocne. Pogłoski o rewizji w koszarach i o przyjeździe Berbeckiego do pułku. Posterunki przy batalionach. O godz. 14.40 wyjazd oficerów, których 22 wysłał Żymierski do Warszawy. Obecnych w pułku było czternastu, ci wyjechali. Pożegnanie uroczyste, orkiestra, owacje. Wobec tego, że wszyscy wyżsi oficerowie wyjechali, komendantem pułku został Sawicki-Sawa porucznik ${ }^{84}$.

${ }^{80}$ Legionista niezidentyfikowany.

${ }^{81}$ Michał Żymierski (1890-1989), właściwie nazywał się Łyżwiński. Używał też nazwiska Żymirski. Studiował prawo na Uniwersytecie Jagiellońskim. Należał do organizacji „Zarzewie”, a później wstąpił do Polskich Drużyn Strzeleckich. W 1912 r. ukończył austriacką szkołę oficerów rezerwy. W 1913 r. zaczął posługiwać się nazwiskiem Żymirski, gdy jego brat Jan zamordował kierownika księgarni Gebethnera i Wolffa. Po protestach rodziny Żymirskich zmodyfikował nazwisko na „Żymierski. W 1914 r. wstąpił do Legionów i służył początkowo jako dowódca kompanii i batalionu I Brygady. W październiku 1914 r. został ciężko ranny w walkach w okolicach Dęblina. Latem 1915 r. w stopniu majora był komendantem Polskiej Organizacji Wojskowej, a od 1916 r. dowodził różnymi jednostkami piechoty. W czasie kryzysu przysięgowego dowodził 2. pułkiem piechoty II Brygady Legionów. Stownik biograficzny ..., t. 2, s. 1776-1767.

${ }_{82}$ Serock, osada miejska na prawym brzegu Narwi z kościołem parafialnym w pow. pułtuskim. SGKP, t. 10, Warszawa 1889, s. 453. Obecnie miasto na południowy wschód od Komorowa odległe od niego ok. $80 \mathrm{~km}$ w pow. legionowskim i woj. mazowieckim.

${ }^{83}$ Jabłonna, wieś i gmina w pow. warszawskim. SGKP, t. 3, Warszawa 1888, s. 346.

${ }^{84}$ Jerzy Sawa-Sawicki (1886-1922), w czasie studiów na Politechnice Lwowskiej wstąpił do PPS i został członkiem Organizacji Bojowej. W 1908 r. wziął udział w słynnej akcji pod Bezdanami. 
Środa 11 VII. Kordegarda do godz. 13. Po obiedzie przyjazd Roji ${ }^{85}$ do pułku. Wizyta w koszarach. Zbiórka kompaniami, bosi (w naszej kompanii 17) demonstracyjnie w pierwszym szeregu. Interwiewy z poszczególnymi żołnierzami. Pytał o buty, wyekwipowanie, a jednocześnie o przysięgę.

Skąd pochodzi? Czy składa przysięgę? Dlaczego nie składa? Czy nie był przymuszony przez oficerów? Mot d'ordre ${ }^{86}$, o którym dowiedziałem się dopiero później, nielogicznie zresztą wobec Rosji było: odpowiadać na pierwsze pytanie - ,z Polski”. W jednej kompanii jeden z żołnierzy zaciął się i na wszystkie pytania odpowiadal - z Polski.

Skąd jesteście? - z Polski. Z jakich okolic? - z Polski. Czy wiecie, kto jestem? - Z Polski. Składaliście przysięgę - Z Polski. Zmiękł na skutek interwencji komendanta kompanii.

Podchodząc do naszej kompanii, Roja rzekł: „Pierwsza - bardzo sympatyczna kompania, same tęgie chłopy. Zwrócił się do mnie: Skąd jesteście? - Z Warszawy. Dawno w służbie? - Od pół roku.

Po wizycie obrady w kasynie (podobno przemówienia) i kategoryczne oświadczenie Roji, że oficerowie do aresztu do Warszawy nie wrócą (przyjechali po rzeczy), a kapitanów z aresztu uwolni. Ogromne zbiegowisko pod kasynem. Asystujący w pobliżu Niemiec spytał, co znaczą owacje. Odpowiedziano mu na kpiny, że pułk wita brygadiera „Wiśniewskiego”. Podobno poszedł do Warszawy telegram informujący, że jakiś brygadier W. przyjechał do pułku.

Owacje na cześć Roji. Orkiestra. Samochód cały ubrany kwiatami i gałęziami. Roja chciał coś powiedzieć, ale go porwano na ręce. Zdążył tylko zawołać: „Niech żyje trzecia brygada”. Zaniesiono go do samochodu. Cała droga do auta zasypana kwiatami.

Czwartek 12 VII. Względny spokój. Wiadomości z przebiegu przysięgi w I pułku, gdzie oficerowie rzucili szable Januszaitisowi ${ }^{87}$. Spodziewanie się

Po wybuchu I wojny światowej wstąpił do Legionów i służył jako oficer w 1., a następnie w 2. pułku piechoty. W 1914 r. został ranny w bitwie pod Łowczówkiem, https://pl.wikipedia.org/wiki/Jerzy_Sawa-Sawicki [dostęp: 05.06.2018].

${ }^{85}$ Bolesław Roja (1876-1940), działał w tajnym ruchu niepodległościowym na obszarze Galicji. Ukończył szkołę kadetów w Wiedniu. Mianowany w 1899 r. podporucznikiem, służył w 36. Pułku Obrony Krajowej w Kołomyi. Ze względu na zły stan zdrowia w 1905 r. został przeniesiony do rezerwy. Współpracował z wywiadem austro-węgierskim. Pracował jako urzędnik kancelaryjny w Krakowie, a także studiował prawo i medycynę na Uniwersytecie Jagiellońskim. Po wybuchu I wojny światowej wstąpił do Legionów Polskich, w których był bliskim współpracownikiem Józefa Piłsudskiego. W 1914 r. dowodził batalionem w 2. pułku piechoty. W roku następnym pełnił funkcję dowódcy 4. pułku piechoty i walczył w bitwie pod Jastkowem. W czerwcu 1917 r. objął dowództwo III Brygady Legionów. H. Korczyk, Roja Bolesław Jerzy, [w:] PSB, t. 31, Wrocław 1988-1989, s. 508-511.

${ }^{86}$ Mot d'ordre, motto, hasło. Wielki stownik francusko-polski, t. 2, Warszawa 1983, s. 108.

${ }^{87}$ Marian Januszajtis-Żegota (1889-1974), studiował na Politechnice Lwowskiej i Akademii Rolniczej w Dublanach, w której uzyskał w 1912 r. dyplom agronoma. Tuż przed wybuchem I wojny światowej podporządkował Polskie Drużyny Strzeleckie, którymi dowodził, Józefowi Piłsudskiemu i wstąpił do Legionów. Dowodził batalionem w 2. pułku piechoty, a potem nim samym w czasie walk 
przysięgi lada chwila. Zbiórki kompanijne i odczytywanie różnych aktualności. Wezwania do zachowania spokoju. Po południu nowe owacje dla przyjeżdżających kapitanów. Salutowanie kapitana niemieckiego, który musiał obejść zwierającą się przed nim grupę żołnierzy. Pułk obejmuje z powrotem major Trojanowski.

Piątek 13 VII. Godz. 10 rano. Zbiórka pułku na placu ćwiczeń pod kapliczką. Pas, ładownica, bagnet, karabin; oficerowie pieszo z białą bronią ręczną. Zwarty czworobok ustawiony dość wolno. Z trzech stron trzy baony, z czwartej kompania karabinów maszynowych, kompania sztabowa, orkiestra etc.

W ostatniej chwili instrukcja dość bałamutna. Królewiacy naprzód, w razie przysięgi łączyć z Galicjanami. Około godz. 10.30 pojawił się w czworoboku Roja z Kaczorowskim ${ }^{88}$, członkiem Tymczasowej Rady Stanu. Krótkie przemówienie Roji. Mamy składać przysięgę, której roty tekst jest nam wiadomy. Kto nie zna tekstu roty - wystąp. Nikt się nie ruszył.

Nie pamiętam, jak związał swoje przemówienie z końcowym okrzykiem na cześć pułku. Niech żyje pułk. Odkrzyknięto trzy razy, coraz ogniściej (za pierwszym razem wiara była trochę, zaskoczona, nie spodziewała się bowiem tego tekstu).

Przemówienie Kaczorowskiego. Wiatr głuszy, on sam cicho mówi. Zwrot między innymi... Pora składania przysięgi i tekst roty nie odpowiada wprawdzie naszym pragnieniem, jednak dla dobra sprawy itd...

Po Kaczorowskim przemawiał znów Roja, krótko, po żołniersku, bardzo donośnie i dobitnie. „Kwestia przysięgi jest sprawą sumienia każdego człowieka. Niech każdy z nas zada sobie pytanie, czy mu sumienie pozwala na złożenie tego rodzaju przysięgi. Wasze proste żołnierskie dusze najlepiej tę sprawę rozstrzygają, ja zaś zastrzegam się, że „zrespektuję” wszelką decyzję. Kto chce złożyć przysięgę - wystąp".

Nie ruszył się nikt. W chwili komendy - „Wystąp”. Ktoś, zdaje się ordynans Roji, przysunął się z zewnątrz czworoboku ku środkowi z paltem. Kaden Bandrowski, widząc to, odłączył się od grupy oficerów i począł biec ku żołnierzowi czy to, żeby płaszcz odebrać, czy żeby wstrzymać ordynansa. Przez chwilę miałem to przykre wrażenie, że może jest ktoś, kto chce przysięgać, a Kaden biegnie, żeby temu gwałtownie zapobiec. Sytuacja się wyjaśniła. Roja Kadena odwołał.

\footnotetext{
w Galicji i na Wołyniu. Dzięki talentowi dowódczemu i odwadze szybko awansował i w 1915 r. został najmłodszym pułkownikiem w Legionach. W lipcu 1916 r., po odejściu Piłsudskiego, objął dowództwo I Brygady i sprawował je do kwietnia 1917 r. W 1917 r. opowiedział się za złożeniem przysięgi na wierność Niemcom i Austro-Węgrom i został szefem sztabu Inspektoratu Wyszkolenia Polskiej Siły Zbrojnej oraz wicedyrektorem Komisji Wojskowej. P. Stawecki, op.cit., s. 146-147.

${ }^{88}$ Antoni Kaczorowski, był zastępcą członka Komisji Przejściowej Tymczasowej Rady Stanu i dyrektorem VI Departamentu (Pracy). Później sprawował funkcję kierownika Ministerstwa Przemysłu i Handlu oraz Opieki Społecznej i Ochrony Pracy. Zmarł nagle na początku 1918 r. Z.J. Winnicki, Rada Regencyjna Królestwa Polskiego i jej organy (1917-1918), Wrocław 2017, s. 30, 104.
} 
Bezpośrednio po przysiędze defilada. Roja, Kaczorowski, grupa sztabowa. Poszło dobrze. Roja pułk witał bardzo serdecznie. Szedłem w pierwszej czwórce. Ledwieśmy doszli do koszar i złożyli broń, krzyki, że Roję niosą. Po przejściu pułku oficerowie wzięli go na ramiona i nieśli do punktu defilady w stronę kasyna. Puściła się wiara w kilkuset chłopa, odebrali Roję oficerom i nieśli dalej aż na kwaterę. Równocześnie poniesiono i majora Trojanowskiego, a bodaj że i innych oficerów. W ogóle harmonia z szarżami nadzwyczajna.

W czasie niesienia Roji Kaczorowski szedł z Kadenem. Mina rzadka zwłaszcza później, gdy odłączywszy się chwilowo od Kadena i wyszedłszy poza druty miał zatarg z szyldwachem niemieckim, który go do koszar nie chciał puścić (to ostatnie znam z opowiadania).

Roję zaniesiono na kwaterę. Stał na ganku, miałem wrażenie, że chce przemówić i jakby czeka na kogoś. Zaczęto się oglądać za Kaczorowskim. Pierwsze, ciche zresztą uwagi na temat jego i Rady Stanu. W końcu Roja ruszył w stronę kasyna. Spotkali się tam z Kaczorowskim i już trzymali razem. Koło nich tłum. Ktoś krzyknął jakiś epitet pod adresem Rady Stanu. Zrobił się mały huczek. Roja huknął i uciszył od razu całe zbiegowisko, po tym żądnych demonstracji nie było wyjąwszy ostentacyjne udekorowanie kwiatami tylko lewej strony samochodu, po której miał siedzieć Roja. Stałem przy aucie i widziałem owe dekoracje. Był zamiar zatknięcia po prawej stronie samochodu suchej gałęzi, ale do tego nie doszło, podobnie jak nie doszło do położenia stryczka na siedzeniu, który to projekt znany mi był później ze słyszenia.

O godz. 14 wyjechałem służbowo po rzeczy kompanijne do Ostrowi.

Sobota 14 VII. Trzynastego wieczorem w Warszawie, na drugi dzień rano w Ostrowi, powrót tego samego dnia po południu do Warszawy, wyjazd do Czaplina $^{89}$. W Górze Kalwarii dowiaduję się o demobilizacyjnym rozkazie. Wieczór w Woli Chynowskiej ${ }^{90}$.

W poniedziałek 16 VII powrót, dowiaduję się w Warszawie o rozbrojeniu i wywożeniu do Szczypiórna. Tatuś robi poszukiwania w obawie, że jestem aresztowany. Zostaję do wtorku (przetrzymuję przepustkę), do pułku wróciłem już po wywiezieniu.

Z opowiadań: Pogłoski o rozbrojeniu rozeszły się w sobotę. Opozycja, zamęt w pułku. Sprzeczność z dotychczasowymi dyrektywami. Polecenie z Warszawy pokojowego złożenia broni. Opozycja. Konsternacja. Wyjazd kpt. Karaszewicza do Warszawy po sprowadzenie dyrektyw.

${ }^{89}$ Czaplin, wieś w gm. Czersk w par. Sobików i w pow. grójeckim. SGKP, t. 1, Warszawa 1880, s. 734. Obecnie w gm. Góra Kalwaria i w pow. piaseczyńskim, i woj. mazowieckim.

${ }_{90}$ Wola Chynowska, wieś w gm. Czersk, w par. Chynów w pow. grójeckim. SGKP, t. 1, Warszawa 1880, s. 669. Obecnie nie istnieje, ponieważ w 2015 r. została włączona do gm. Chynów w pow. grójeckim i woj. mazowieckim. 
Niedziela 15 VII. Definitywne instrukcje złożenia broni o 9 rano. O 11 przed południem rozbrojenie. W południe pierwsza wiadomość o wyjeździe Królewiaków i o masowych aresztowaniach w $\mathrm{POW}^{91}$.

Poniedziałek 16 VII. Wiadomość o złożeniu broni przez IV pułk. Godz. 20 wyjazd Królewiaków. Nastrój zrazu fatalny. W czasie samego wyjazdu podniecenie i humor nadzwyczajny. Prowadzi transport Olszyna. Major Harzbruck ${ }^{92}$, Niemiec, proponuje eskortę niemiecką wobec tego, że z poprzednich transportów sporo uciekło. Trojanowski zaręczył słowem, że nikt nie ucieknie. Do Szczypiórna dojechało o 17 więcej niż wyjechało z Różana.

Na dworcu w czasie odjazdu przemówienie Malskiego ${ }^{93}$, który żegnał w imieniu Galicjan. W czasie przemówienia aresztowano szpicla kobietę, która notowała przemówienie. Osadzono ją w kordegardzie.

Czwartek 19 VII. Pogłoski o tym, że 1) Major Mężyński ${ }^{44}$ zostaje komendantem pułku. 2) Oficerowie trzeciego pułku obejmują komendę w piątym pułku. 3) Władze austriackie kokietują zwolnionych i dezerterów. 4) Austriaccy poddani mają wyjechać do Oświęcimia.

Na Piłsudskiego dokonano zamachu.

Wyjazd grupy footbalistów do Krakowa.

Tyle raptularz. Tchnie on chaosem, jakąś niezdarną, chwiejną, rozlazłą anarchią. Był to już początek końca legionowej pieśni tak dumnie zaczętej przed trzema laty w Oleandrach ${ }^{95}$. Do tej chwili nie rozumiem, dlaczego Piłsudski zgodził się na taki niesławny koniec swego dzieła, gdy mógł był przecież schować Legiony pod ziemię POW, które wtedy, o ile wiem, stało organizacyjnie wysoko i mogło było $\mathrm{z}$ łatwością pomieścić owe kilkanaście tysięcy dezerterów.

${ }^{91}$ Polska Organizacja Wojskowa, tajna organizacja wojskowa powstała w sierpniu 1914 r. w Warszawie z inicjatywy Józefa Piłsudskiego, której celem była walka o niepodległość. Nazwy tej używała od października 1914 r. Działała do 1918 r. Mała Encyklopedia Wojskowa, t. 2, Warszawa 1970, s. 711-712.

${ }_{92}$ Major Harzbruck, skądinąd nieznany.

${ }^{93}$ Władysław Malski (1894-1941), działacz spółdzielczy i społeczny, legionista, członek POW, oficer wywiadu Wojska Polskiego. Studiował przyrodoznawstwo na Uniwersytecie Jagiellońskim. W 1913 r. wstąpił do Związku Strzeleckiego. Po wybuchu I wojny światowej wstąpił do Legionów i służył w 5. pułku piechoty I Brygady. L. Hass, Malski Władysław Antoni, [w:] PSB, t. 19, Wrocław 1974, s. 382-383.

${ }^{94}$ Włodzimierz Józef Mężyński (1889-1918), był aktywnym działaczem Polskiej Partii Socjalno-Demokratycznej Galicji i Śląska Cieszyńskiego. Od 1912 r. należał do Związku Strzeleckiego. W 1914 r. po wybuchu I wojny światowej zorganizował oddział Strzelców w Bielsku i wstąpił z nim w Krakowie do 2. pułku piechoty Legionów. Dowodził w nim plutonem, kompanią, batalionem, a przez pewien czas także pułkiem i awansował od stopnia chorążego do stopnia majora (w $1915 \mathrm{r}$.). Zmarł 10 lutego 1918 r. na atak serca w szpitalu garnizonowym w Krakowie. A. Pilch, A. Szklarska-Lohmanowa, Mężýnski Włodzimierz Józef, [w:] PSB, t. 20, Wrocław 1975, s. 519.

${ }_{95}$ W budynku teatru ogródkowego „Oleandry” w Krakowie w sierpniu 1914 r. nocowali żołnierze 1. Kadrowej Kompanii i stąd wyruszyli na wojnę. Budynek ten został zburzony podczas I wojny światowej, a przez teren, na którym się on znajdował, przechodzi obecnie ulica Oleandry. Encyklopedia Krakowa, Kraków 2000, s. 697. 
Wspomnienia moje z tego okresu są nad wyraz przykre. Po powrocie do pułku trafiłem na przygotowania do wymarszu. Takich jak ja Królewiaków, którzy nie trafili do Szczypiórna, było kilku. Kazali nam przyłączyć się do transportu. Odbyłem więc ostatnią drogę piątego pułku, przejazd do Siedlisk ${ }^{96}$ pod Przemyślem, gdzie jak się okazało miała na nas czekać likwidacja.

Likwidacja faktyczna wyprzedziła formalną. Rozprzężenie rosło z dnia na dzień. Rozdrapywano mienie pułkowe, sprzedawano na lewo i prawo wszystko, cokolwiek mogło mieć nabywcę, począwszy od koca skończywszy na koniu.

Zbliżał się dla mnie kres mojej służby wojskowej. Pozostawanie na miejscu groziło mi wcielenie do wojska austriackiego, co już najmniej leżało w mych intencjach. Cóż było robić. Nie pamiętam już, z własnego impulsu czy skierowany przez jakąś narzuconą mi z boku czy z góry (o ile taka góra w ogóle istniała), słowem przez pułk, dyrektywę, zwiałem do wojska. Odbyło się to gładko za jakimś na wpół legalnym dokumentem pułkowym. Wylądowałem w Sandomierskiem i tam zapuściłem kotwicę na paromiesięczne leże. Tam też bodaj czy też może w Krakowie odnalazła mnie depesza Józefa Mikułowskiego-Pomorskiego ${ }^{97}$, naówczas dyrektora Departamentu Wyznań Religijnych i Oświecenia Tymczasowej Rady $\operatorname{Stanu}^{98} \mathrm{z}$ propozycją, bym w tymże departamencie objął stanowisko sekretarza generalnego.

Nowa improwizacja w mym życiu, nowy nieobliczalny krok wzwyż, nowa błyskawiczna, acz grożąca skręceniem karku „kariera”, nowa niezwalczona dla młodego pokusa.

Przyjąłem.

Polska Akademia Nauk Archiwum w Warszawie, zesp. III-399 Materiały Kazimierza Konarskiego, sygn. 11, s.1-26, kopia, mps.

${ }^{96}$ Siedliska, wieś w pow. przemyskim, odległa o $9 \mathrm{~km}$ na południowy wschód od Przemyśla. SGKP, t. 10, Warszawa 1889, s. 512-513. Na jej skraju znajdował się fort artyleryjski „Salis Soglio”, stanowiący ważny element twierdzy Przemyśl. Wzniesiono go w 1. 1882-1886, a jego nazwa pochodziła od nazwiska szwajcarskiego inżyniera i austriackiego generała, który w 1. 1871-1875 kierował budową umocnień twierdzy przemyskiej. T. Idzikowski, Forty twierdzy Przemyśl, Przemyśl 2001, s. $39-12$.

${ }^{97}$ Józef Mikułowski-Pomorski (1868-1935), w 1889 r. ukończył Wydział Agronomiczny Politechniki w Rydze. W 1893 r. został asystentem na Akademii Rolniczej w Dublanach, a w 1900 r. profesorem. Zorganizował w niej chemiczno-rolniczą stację badawczą i doświadczalną i w 1. 1906-1911 był jej dyrektorem. W 1911 r. przeniósł się do Warszawy, gdzie w 1916 r. został członkiem zarządu Towarzystwa Polskiej Macierzy Szkolnej. W 1. 1916-1917 był wicemarszałkiem Tymczasowej Rady Stanu (1916-1917) oraz członkiem jej Komisji Przejściowej. A. Żabko-Potopowicz, Mikułowski Pomorski Józef Karol Mateusz, [w:] PSB, t. 21, Wrocław 1976, s. 187-190.

98 J. Mikułowski-Pomorski sprawował funkcję dyrektora najpierw Referatu, a potem Departamentu Wyznań Religijnych i Oświecenia Publicznego Tymczasowej Rady Stanu, pełniąc jednocześnie funkcję dyrektora biura tego departamentu. Ibidem, s. 188. 
Na pierwszej karcie dokumentu odręczna adnotacja autora $\mathrm{z}$ datą dopisaną ołówkiem: „Rozdział o służbie mojej w Legionach, skreślony przez cenzurę w czasie druku Pamiętników we wrocławskim Ossolineum. Z miłym i dobrym słowem Kochanemu Piotrowi Bańkowskiemu K. Konarski 14 XI 67”.

\section{Bibliografia}

Bańkowski P., Kazimierz Konarski (1886-1972), „Archeion” 1973, t. 59, s. 345-353.

Bąbiński K., Zarys historii wojennej 5-go pułku piechoty Legionów, Warszawa 1929.

Bielińska M., Wąsowicz M., Bańkowski Piotr, [w:] Stownik biograficzny archiwistów polskich, t. 1, 1918-1984, red. M. Bielińska i I. Janosz-Biskupowa, Warszawa-Lódź 1988, s. 32-34.

Chodkowska A., Materiaty Kazimierza Konarskiego (1886-1972), „Biuletyn Archiwum Polskiej Akademii Nauk" 2008, nr 49, s. 103-109.

Drozdowski M.M., Starzyński Stefan, [w:] Polski stownik biograficzny, t. 42, Wrocław 2003-2004, s. $485-493$.

Handelsman M., Brudziński Polikarp Józef, [w:] Polski słownik biograficzny, t. 3, Kraków 1937, s. $11-12$.

Hass L., Malski Władysław Antoni, [w:] Polski stownik biograficzny, t. 19, Wrocław 1974, s. 382 383.

Idzikowski T., Forty twierdzy Przemyśl, Przemyśl 2001.

Ihnatowicz I., Projekt instrukcji wydawniczej dla źródeł historycznych XIX i początku XX wieku, „Studia Źródłoznawcze” 1962, t. 7, s. 99-124.

Konarski K., Dalekie a bliskie. Wspomnienia szczęśliwego człowieka, Wrocław 1965.

Korczyk H., Roja Bolesław Jerzy, [w:] Polski słownik biograficzny, t. 31, Wrocław 1988-1989, s. $508-511$.

Kozak Z., Starzyński Roman, [w:] Polski słownik biograficzny, t. 42, Warszawa 2003-2004, s. 474-477.

Krwawicz M., Maxymowicz-Raczyński Włodzimierz Marian, [w:] Polski słownik biograficzny, t. 20, Wrocław 1975, s. 269-270.

Krwawicz M., Olszyna-Wilczyński Józef Konstanty, [w:] Polski słownik biograficzny, t. 24, Wrocław 1979, s. 52-53.

Kwiatek J., Litewski T., Leksykon miast polskich, Warszawa 1998.

Landau Z., Składkowski Stawoj Felicjan, [w:] Polski słownik biograficzny, t. 38, Warszawa 1997, s. 193-197.

Łosowski J., Wspomnienia Kazimierza Konarskiego z okresu wojny jako obraz przeżyć jednostki w okresie zmagań z dwoma systemami totalitarnymi, [w:] Wktad archiwistów warszawskich w rozwój archiwistyki polskiej. Zbiór studiów poświęconych warszawskiemu środowisku archiwalnemu, red. A. Kulecka, Warszawa 2012, s. 323-344.

Łosowski J. Wspomnienia legionowe Kazimierza Konarskiego, [w:] Zarządzanie dokumentacja, archiwistyka i... koty. Księga jubileuszowa Profesor Haliny Robótki, red. R. Degen, M. Jabłońska, W.K. Roman, Toruń 2016, s. 217-226. 
Maciejewska W., Konarski Kazimierz Bogdan, [w:] Stownik biograficzny archiwistów polskich, t. 1, 1918-1984, red. M. Bielińska i I. Janosz-Biskupowa, Warszawa-Lódź 1988, s. 104-106.

Niedźwiedź J., Leksykon historyczny miejscowości dawnego województwa zamojskiego, Zamość 2003.

Pilch A., Szklarska-Lohmanowa A., Mężyński Włodzimierz Józef, [w:] Polski słownik biograficz$n y$, t. 20, Wrocław 1975, s. 519.

Rubacha J., Korpus Landwehry w bojach o Baranowicze latem 1916, „Słupskie Studia Historyczne" 2010, nr 16, s. 73-83.

Składkowski F.S., Strzępy meldunków, Warszawa 1936.

Stownik biograficzny historii Polski, pod red. J. Chodery i F. Kiryka, t. 2, Wrocław 2005.

Słownik geograficzny Królestwa Polskiego, t. I, Warszawa 1880; t. VII, Warszawa 1888.

Sprusiński M., Kaden Bandrowski Juliusz, [w:] Polski słownik biograficzny, t. 11, Wrocław 1964 1965, s. 401-404.

Stawecki P., Stownik biograficzny generałów Wojska Polskiego 1918-1939, Warszawa 1994.

Szarota T., Rowecki Stefan Pawet, [w:] Polski stownik biograficzny, t. 32, Wrocław 1989-1991, s. 333-338.

Winnicki Z.J., Rada Regencyjna Królestwa Polskiego i jej organy (1917-1918), Wrocław 2017.

Zagłębie Dąbrowskie w czasach zaborów i walk o niepodległość (do roku 1918), red. J. Walczak, Sosnowiec 2004.

Żabko-Potopowicz A., Mikułowski Pomorski Józef Karol Mateusz, [w:] Polski słownik biograficzny, Wrocław 1976, s. 187-190. 